
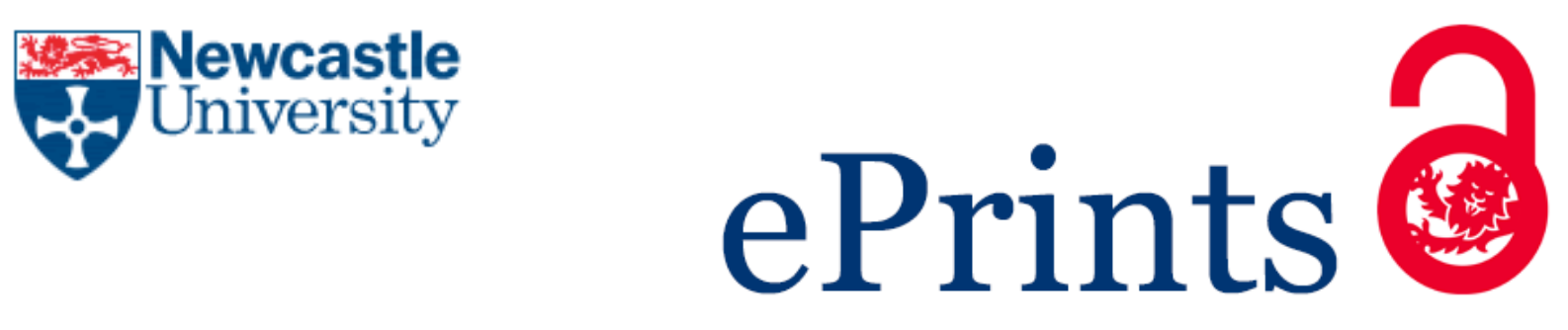

Christensen PA, Yonar T, Zakaria K. The Electrochemical Generation of Ozone: A Review. Ozone: Science \& Engineering 2013, 35(3), 149-167.

\title{
Copyright:
}

This is an Accepted Manuscript of an article published by Taylor \& Francis in Ozone: Science \& Engineering on 23-04-2013, available online:

http://www.tandfonline.com/10.1080/01919512.2013.761564

Date deposited:

$08 / 02 / 2016$

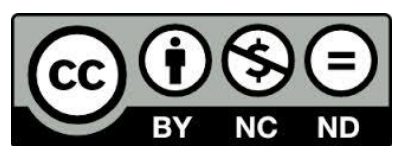

This work is licensed under a

Creative Commons Attribution-NonCommercial-NoDerivatives 4.0 International licence 


\section{The Electrochemical Generation of Ozone: A Review}

Paul Andrew Christensen*a ${ }^{\mathrm{a}}$, Taner Yonar ${ }^{\mathrm{c}}$ and Khalid Zakaria ${ }^{\mathrm{c}}$.

${ }^{a}$ School of Chemical Engineering and Advanced Materials, Bedson Building, Newcastle University, Newcastle upon Tyne, NE1 7RU

${ }^{\mathrm{b}}$ Uludağ Universitesi,16059, Bursa, Turkey.

${ }^{c}$ School of Civil Engineering and Geosciences, Bedson Building, Newcastle University, Newcastle upon Tyne, NE1 7RU

\section{ABSTRACT}

This paper reviews work on the electrochemical generation of ozone from the original studies by Schönbein in the early 1800 's to the present day, and is intended for specialists and non-specialists in the field of electrochemistry. The experimental techniques employed to study the mechanism of electrochemical ozone generation are described, as is the most commonly quoted mechanism and the experimental evidence for the mechanism is summarised and discussed. The types of electrochemical cells employed are described, and the effect of: temperature, anode type and composition, current density and electrolyte composition $\& \mathrm{pH}$ are discussed.

\section{KEYWORDS}

Ozone, cell, history, zero-gap, membrane, electrodes, air-breathing, Schönbein, review.

\section{Introduction}

Ozone was first identified as a distinct chemical compound by Schönbein in work that commenced with his observation that the electrolysis of water produced an odour at the anode identical to that from an electric arc (Schönbein, 1838-1840). Schönbein's acquisition of a Grove cell, which was able to deliver a much higher current than his previous apparatus, led to his proposal that the odour was due to a distinct chemical (Schönbein, 1840a), which he named "ozone" (Schönbein, 1840b). There is a nice circularity in the acquisition of the Grove cell by Schönbein in the mid- $19^{\text {th }}$ century being so critical to the discovery of ozone and the use of air cathodes in electrochemical ozone cells in the $21^{\text {st }}$ century (see, for example, (Wang et al., 2006)). For an in-depth review of Schönbein's work see (Rubin, 2001). 
The molecular formula of ozone was determined by Andrews and Tait (Andrews and Tait, 1860), only after which could the compound be determined quantitatively.

The electrolysis of water is generally believed to produce ozone via a 6-electron process (Da Silva et al., 2003a; Da Silva et al., 2006):

$$
3 \mathrm{H}_{2} \mathrm{O} \rightarrow \mathrm{O}_{3}+6 \mathrm{H}^{+}+6 \mathrm{e}^{-} \quad \mathrm{E}^{\circ}=+1.51 \mathrm{~V}
$$

As $\mathrm{E}^{\circ}$ for the oxidation of water to oxygen is somewhat lower, +1.23 V (Bard et al., 1985):

$$
2 \mathrm{H}_{2} \mathrm{O} \rightarrow \mathrm{O}_{2}+4 \mathrm{H}^{+}+4 \mathrm{e}^{-} \quad \mathrm{E}^{\circ}=+1.23 \mathrm{~V}
$$

oxygen is always produced simultaneously with ozone ((Da Silva et al., 2006) and references therein), and the current efficiency for ozone generation is the percentage of the observed current that is generating ozone.

Ozone is not always observed as soon as Faradaic current (ie. electrons cross the electrode/electrolyte interface) flows: at $\mathrm{PbO}_{2}$ anodes (the most commonly employed electrodes for ozone generation), Kötz and Stucki (Kotz and Stucki, 1987), report that ozone was only observed at current densities $>50 \mathrm{~mA}$ $\mathrm{cm}^{-2}$ whilst and co-workers did observe ozone as soon as Faradaic current flows (Feng et al., 1994). At $\mathrm{Si} / \mathrm{TiO}_{\mathrm{x}} / \mathrm{Pt} / \mathrm{TaO}_{\mathrm{x}}$ anodes, Kaneda et al., (Kaneda et al., 2006) observe an onset of ozone evolution at current densities $>30 \mathrm{~mA} \mathrm{~cm}^{-2}$.

The solubility of ozone in acidic solutions is generally accepted as being up to ca. 10 times that of $\mathrm{O}_{2}$ (De Smedt et al., 2001; Levanov et al., 2008; Seidel, 2006) i.e. the saturation solubility at $0{ }^{\circ} \mathrm{C}$ and 1 atm is $22 \mathrm{mM}$.

Ozone is commonly measured in the gas phase and solution by UV spectroscopy and iodometric titration (Gordon et al., 1988). The UV approach employs the ozone peak near $254 \mathrm{~nm}$ (gas phase) or $258 \mathrm{~nm}$ (solution phase) (Stucki et al., 1985). The majority of papers in the literature quote a value of $3000 \pm 125 \mathrm{~mol}^{-1} \mathrm{dm}^{3} \mathrm{~cm}^{-1}$ for both the gas and aqueous phase extinction coefficients (see, for example, (Hoigne and Bader, 1976; Kilpatrick et al., 1956; Nemes et al., 2000)) with a typical gas phase value 
of $3024 \mathrm{~mol}^{-1} \mathrm{dm}^{3} \mathrm{~cm}^{-1}$ at $254 \mathrm{~nm}$ and aqueous phase value of $2900 \mathrm{~mol}^{-1} \mathrm{dm}^{3} \mathrm{~cm}^{-1}$ at $258 \mathrm{~nm}$ (Stucki et al., 1985). The International Ozone Association (Nemes et al., 2000), recommends a value of 3000

$\mathrm{mol}^{-1} \mathrm{dm}^{3} \mathrm{~cm}^{-1}$. It is worth mentioning that some concerns have been expressed with respect to the adverse effect of water vapour on the UV analysis of low concentrations of gas phase ozone (Meyer et al., 1991).

Iodometric titration is the standard method recommended by the International Ozone Association (Rakness et al., 1996). Briefly, the iodometric method relies on the oxidation of $\mathrm{I}^{-}$by $\mathrm{O}_{3}$ followed by the determination of the amount of iodine so formed by titration with sodium thiosulfate using starch indicator.

\section{The mechanism of electrochemical ozone generation}

With any chemical or electrochemical reaction, a good place to start is to identify the intermediates. Wabner and Grambow, employed various methods to detect hydroxyl radicals, singlet oxygen and peroxo species $\left(\mathrm{H}_{2} \mathrm{O}_{2}\right.$ and $\left.\mathrm{HOO}\right)$ during the electrolysis of $\mathrm{pH} 7$ phosphate buffer at $\mathrm{Pt}$ and $\mathrm{PbO}_{2}$ anodes (Wabner and Grambow, 1985). The spin trap p-nitrosodimethyl aniline (NDMA) was employed to detect $\mathrm{OH}$ radicals, via the bleaching of the NDMA absorption at $\lambda_{\max }=440 \mathrm{~nm}$; singlet oxygen was monitored via its reaction with histidine and the bleaching of the $440 \mathrm{~nm}$ absorption of NDMA by the endoperoxides so formed. Peroxo species were detected via their conversion to $\mathrm{OH}$ radicals by $\mathrm{Fe}^{2+}$ and reaction with NDMA. Pt was used for comparison with $\mathrm{PbO}_{2}$ as the former did not produce ozone at the low current densities employed $\left(5 \mathrm{~mA} \mathrm{~cm}{ }^{-2}\right.$ ). As well as $\mathrm{O}_{2}, \mathrm{Pt}$ and $\mathrm{PbO}_{2}$ both produced singlet oxygen; however, Pt produced peroxo species and only traces of $\mathrm{OH}$ radicals, whilst $\mathrm{OH}$ radicals were clearly produced at the $\mathrm{PbO}_{2}$. On the basis of their results, the authors concluded that $\mathrm{OH}$ radicals were intermediates in the production of ozone:

$$
\begin{aligned}
& \mathrm{H}_{2} \mathrm{O} \rightarrow \mathrm{OH}_{\mathrm{ads}}+\mathrm{H}^{+}+\mathrm{e}^{-} \\
& \mathrm{OH}_{\mathrm{ads}}+\mathrm{O}_{2 \mathrm{ads}} \rightarrow \mathrm{HO}_{3 \mathrm{ads}} \\
& \mathrm{HO}_{3 \mathrm{ads}} \rightarrow \mathrm{HO}_{3}^{+}+\mathrm{e}^{-} \\
& \mathrm{HO}_{3}{ }^{+} \rightarrow \mathrm{O}_{3}+\mathrm{H}^{+}
\end{aligned}
$$


Kim and Korshin also detected $\mathrm{OH}$ radicals during the electrolysis of aqueous $\mathrm{Na}_{2} \mathrm{SO}_{4}$ at $\mathrm{PbO}_{2}$ and postulated that these species were intermediates in electrochemical $\mathrm{O}_{3}$ generation (Kim and Korshin, 2008), and this remains a common postulate (Da Silva et al., 2001, 2003a; Da Silva et al., 2006; Feng et al., 1994; Franco et al., 2006; Franco et al., 2008; Santana et al., 2005), with the first step (3), the primary water discharge, being the rate determining step (rds).

The gas phase reaction:

$$
\left(\mathrm{O}^{*}\right)_{(\mathrm{g})}+\mathrm{O}_{2} \rightarrow \mathrm{O}_{3}
$$

is well known to proceed with low activation energy (Eliasson and Kogelschatz, 1986), and the role of atomic oxygen as a key intermediate to $\mathrm{O}_{3}$ has hence also long been postulated in electrochemistry (see, for example, (Foller and Tobias, 1982)). Initially, dissolved $\mathrm{O}_{2}$ was believed to be the other reactant (Beaufils et al., 1999; Stucki et al., 1985). Stucki and co-workers employed a pressured membrel electrolyzer (Stucki et al., 1987), to investigate the possible role of dissolved $\mathrm{O}_{2}$, but found that pressure had no effect upon current efficiency, an observation they rationalised in terms of the reactions:

$$
\begin{gathered}
k_{1} \\
(\mathrm{O})_{\mathrm{ads}}+\mathrm{O}_{2(\mathrm{~g})} \rightarrow \mathrm{O}_{3(\mathrm{~g})} \\
k_{2} \\
(\mathrm{O})_{\mathrm{ads}}+\mathrm{O}_{3(\mathrm{~g})} \rightarrow \mathrm{O}_{2(\mathrm{~g})}
\end{gathered}
$$

Increasing the pressure increases $\mathrm{O}_{3}$ and $\mathrm{O}_{2}$ but decreases $(\mathrm{O})_{\text {ads }}$, hence the ratio of the two reaction rates (8) and (9) remains unchanged. Reactions (8) and (9) show another commonly held view, that $\left(\mathrm{O}^{*}\right)_{\text {ads }}$ is common to both $\mathrm{O}_{2}$ and $\mathrm{O}_{3}$ formation, and it is now generally accepted that adsorbed $\mathrm{O}_{2}$ is the active intermediate, along with $\left(\mathrm{OH}^{*}\right)_{\text {ads }}$ and $\left(\mathrm{O}^{*}\right)_{\text {ads }}$ (Babak et al., 1994; Beaufils et al., 1999; Feng et al., 1994), and that the discharge of water is the rate determining step.

Mechanistic studies on electrochemical ozone evolution have primarily focused on the interpretation of overpotential vs $\log$ (current density), or Tafel, plots (see Appendix for a critical description of the Tafel 
approach; current density in $\mathrm{A} \mathrm{cm}^{-2}$ ). Broadly speaking, in terms of the first two postulated steps in electrochemical ozone evolution:

$$
\begin{aligned}
& \left(\mathrm{H}_{2} \mathrm{O}\right)_{\mathrm{ads}} \rightarrow\left(\mathrm{OH}^{\cdot}\right)_{\mathrm{ads}}+\mathrm{H}^{+}+\mathrm{e}^{-} \quad(\text { rate determining step }) \\
& \left(\mathrm{OH}^{\cdot}\right)_{\mathrm{ads}} \rightarrow\left(\mathrm{O}^{\cdot}\right)_{\mathrm{ads}}+\mathrm{H}^{+}+\mathrm{e}^{-}
\end{aligned}
$$

if all the species in (10) and (11) were in solution, ie. (10) and (11) are outer sphere processes, we would expect the slope of the Tafel plot to be $118 \mathrm{mV}$, if (10) was rate limiting, or $39 \mathrm{mV}$ if (11) was the rds (Hamann et al., 2007; Oldham and Myland, 1994). In the latter case, at high enough overpotentials, there should be a switch of the rds to (10) with a concomitant increase in the slope to $118 \mathrm{mV}$. If any adsorbed species are involved (as is the case with (10) and (11)), the analysis becomes significantly more complicated and a range of Tafel slopes are possible. The above analysis requires that the mass transport of reactants to the electrode and of products away from the electrode is controlled; in most papers reporting Tafel analyses, this is not the case.

The work of Kötz and Stucki may be considered as seminal in the Tafel-based analysis of the ozone evolution reaction for several reasons (Kotz and Stucki, 1987). The authors studied the electrolysis of $3 \mathrm{M} \mathrm{H}_{2} \mathrm{SO}_{4}$ at (static) $1 \mathrm{~cm}^{2} \mathrm{PbO}_{2}$ anodes at $0{ }^{\circ} \mathrm{C}$, measuring current density as a function of the electrode potential, and the data so obtained are shown in fig. 1. The authors drew attention to the important fact that the method of IR compensation (to take into account the resistance of the electrolyte as well as any insulating films that may form on the electrode, etc) is crucial, as different methods can give rise to markedly different results, as may be seen in fig. 1, see curve (I). The authors employed the current interruption method (solid line) and the positive feedback approach (dashed line). As may be seen from the figure, at low overpotentials/current densities, there is no difference in the data obtained via the two approaches; however, at high current densities the two methods diverge quite markedly. The correct choice of IR compensation remains a major concern in such experiments (Da Silva et al., 2001; Franco et al., 2006). Kötz and Stucki decided that current interruption method was appropriate, and interpreted the switch from a Tafel slope of $120 \mathrm{mV}$ at low overpotentials $(<50 \mathrm{~mA}$ $\mathrm{cm}^{-2}$ ) to $70 \mathrm{mV}$ at high overpotentials (the axes are reversed with respect to conventional Tafel plots) to the formation of $\mathrm{OH}_{\mathrm{ads}}$ or $\mathrm{O}_{\mathrm{ads}}$ becoming the rds, as ozone formation was only observed in the region of the lower Tafel slope. The current leading to ozone formation was calculated by the authors via the UV analysis of the gas evolved from the anode, employing an extinction coefficient of $3024 \mathrm{~mol}^{-1} \mathrm{dm}^{3}$ 
$\mathrm{cm}^{-1}$ for the $\lambda_{\max }$ of $\mathrm{O}_{3}$ at $254 \mathrm{~nm}$, and is shown as curve (Katsuki et al.) in fig. 1. The slope of the “ozone Tafel plot" so obtained was found to be $70 \mathrm{mV}$ and this was interpreted in terms of a reaction common to $\mathrm{O}_{2}$ and $\mathrm{O}_{3}$ generation that becomes rds at higher current densities; overall the authors postulated the mechanism shown in fig. 2. The 'oxide path' mechanism referred to in fig. 2 was postulated by Bockris and Reddy (Bockris and Reddy, 1973) and concerned the evolution of oxygen at Pt electrodes and postulates that the first step, the primary water discharge, is the rds based on the ratio of the number of electrons transferred $(n=4)$ to the forward and backward asymmetry parameters (both taken as 0.5 ).

The model proposed by Kötz and Stucki (Kotz and Stucki, 1987) is the most commonly accepted, general mechanism for electrochemical ozone generation essentially irrespective of anode material, has remained at the core of the mechanisms proposed for electrochemical ozone evolution since, and is typified by the model postulated by Da Silva and co-workers (Da Silva et al., 2001, 2003a):

$$
\begin{aligned}
& \left(\mathrm{H}_{2} \mathrm{O}\right)_{\mathrm{ads}} \rightarrow\left(\mathrm{OH}^{\cdot}\right)_{\mathrm{ads}}+\mathrm{H}^{+}+\mathrm{e}^{-}(\mathrm{rds}) \\
& \left(\mathrm{OH}^{\cdot}\right)_{\mathrm{ads}} \rightarrow\left(\mathrm{O}^{\cdot}\right)_{\mathrm{ads}}+\mathrm{H}^{+}+\mathrm{e}^{-} \\
& \left(\mathrm{O}^{\cdot}\right)_{\mathrm{ads}} \rightarrow[1-\theta]\left(\mathrm{O}^{*}\right)_{\mathrm{ads}}+\theta\left(\mathrm{O}^{\cdot}\right)^{*}{ }_{\mathrm{ads}}(0<\theta<1) \\
& {[1-\theta]\left(2 \mathrm{O}^{\cdot}\right)_{\mathrm{ads}} \rightarrow[1-\theta]\left(\mathrm{O}_{2}\right)_{\mathrm{ads}}} \\
& {[1-\theta]\left(\mathrm{O}_{2}\right)_{\mathrm{ads}} \rightarrow[1-\beta] \cdot[1-\theta]\left(\mathrm{O}_{2}\right)_{\mathrm{ads}}+\beta[1-\theta]\left(\mathrm{O}_{2}\right)^{*}{ }_{\mathrm{ads}}(0<\beta<1)} \\
& {[1-\beta] \cdot[1-\theta]\left(\mathrm{O}_{2}\right)_{\mathrm{ads}} \rightarrow \mathrm{O}_{2} \uparrow} \\
& \theta\left(\mathrm{O}^{\cdot}\right)^{*}{ }_{\mathrm{ads}}+\beta[1-\theta]\left(\mathrm{O}_{2}\right)^{*} \text { ads } \rightarrow[\theta+\beta(1-\theta)]\left(\mathrm{O}_{3}\right)_{\mathrm{ads}} \\
& {[\theta+\beta(1-\theta)]\left(\mathrm{O}_{3}\right)_{\mathrm{ads}} \rightarrow \mathrm{O}_{3} \uparrow}
\end{aligned}
$$

" $\theta$ " and " $\beta$ " represent the surface coverage by oxygen species while "**" represent the fractional surface coverage of intermediates leading to $\mathrm{O}_{3}$. 
The majority of papers concerning the kinetics of electrochemical ozone evolution interpret data in terms of the principles detailed above. In general, and after suitable IR correction, Tafel plots are found to exhibit two linear regions (as observed by (Kotz and Stucki, 1987)) corresponding to $\mathrm{O}_{2}$ evolution at low current densities and $\mathrm{O}_{2}+\mathrm{O}_{3}$ at high current densities (Franco et al., 2006)). The change in slope is taken as showing a transition in the rds and/or of the asymmetry parameter $\beta$ (see, for example (Da Silva et al., 2001; Da Silva et al., 2003b) $\left(\mathrm{PbO}_{2}\right)$ and (Santana et al., 2004, 2005) $\left(\mathrm{IrO}_{2}+\mathrm{Nb}_{2} \mathrm{O}_{5}\right)$. Based on the Tafel equation (see Appendix), the Tafel slope should be linearly dependent upon temperature; however, such a simple dependence is not observed (Da Silva et al., 2003a), and this was interpreted in terms of the effect of bubble adherence (especially at high current densities) and/or anion adsorption, both of which will have significant effect upon the observed Tafel slope, illustrating again that Tafel measurements have to be interpreted with great care. It is also clear from the literature that anions can have a very significant effect upon ozone efficiency, and this is dealt with in a separate section below.

\section{The electrochemical cell}

The types of cell employed in the electrochemical generation of $\mathrm{O}_{3}$ reflect those generally employed in electrolysis.

In the simplest cell configuration, the electrodes are immersed directly in the electrolyte (Putnam et al., 1948) and the gases evolved at anode and cathode are allowed to mix, see fig. 3. Separated cells employ an inert separator such as glass (Da Silva et al., 2003a; Putnam et al., 1948; Putnam, 1948; Seader and Tobias, 1952), wetted Teflon (Foller and Kelsall, 1993; Seader and Tobias, 1952) or Nafion (Kim and Korshin, 2008; Michaud et al., 2003) and the anode and cathode gases are vented separately, see figs. 4(a) and (b).

Zero gap, filter-press and Membrane Electrolyte Assembly (MEA)-based cells employ a solid polymer electrolyte (SPE) membrane (typically Nafion) as the electrolyte, with the anode and cathode being pressed tightly against the membrane. Protons can move through pores in the membrane and hence maintain the essential, ionic conductivity between the electrodes (Larminie and Dicks, 2003). In MEAbased cells, the membrane is hot-pressed between the anode and cathode to form a free-standing MEA prior to inclusion in the cell (Katoh et al., 1994; Wang et al., 2006); otherwise the electrodes are pressed tightly either side of the membrane mechanically (Arihara et al., 2007). 
If water is fed to a Pt-based cathode (e.g. Pt or Pt/Ti mesh), hydrogen is evolved as the cathode reaction (Arihara et al., 2007; Beaufils et al., 1999; Da Silva et al., 2010; Han et al., 2006; Onda et al., 2005; Stucki et al., 1987; Tatapudi and Fenton, 1993), see fig. 5. In contrast, if an air breathing cathode is employed (i.e. Pt particles deposited upon porous carbon in a gas diffusion electrode), oxygen is reduced to water at the cathode (Bockris and Reddy, 1973; Cui et al., 2009; Wang et al., 2006), which is a safer system, especially for domestic applications. In principle there is an additional advantage in using such a cathode. Given that cell voltage is the difference between the two individual electrode potentials (anode and cathode), the potential of a hydrogen evolving cathode should be $0 \mathrm{~V}$ vs the Reversible Hydrogen Electrode (RHE, a standard reference electrode, see (Hamann et al., 2007), p. 93 ff) based (only) on thermodynamic considerations (ie. ignoring kinetic effects, see below), whilst oxygen reduction should occur at $1.23 \mathrm{~V}$ vs RHE. Hence, the cell voltage required to drive ozone evolution at a particular rate should be less when employing an air cathode compared to a hydrogen evolving cathode. Thus, Katoh and co-workers monitored the anode and cathode potentials during electrolysis of water in a zero gap cell employing a $\beta-\mathrm{PbO}_{2}$ anode and air breathing cathode fed with pure oxygen or with no oxygen and so allowed to generate hydrogen; the authors found that the cell voltage observed at $1 \mathrm{~A} \mathrm{~cm}^{-2}$ using the oxygen cathode was $0.85 \mathrm{~V}$ lower than when hydrogen was evolved (Katoh et al., 1994).

There are a number of reports on variations of the zero gap cell, e.g. feeding humidified $\mathrm{O}_{2}$ to a gas diffusion cathode to generate $\mathrm{H}_{2} \mathrm{O}_{2}$ (Tatapudi and Fenton, 1994) using an air breathing cathode/Nafion "half MEA" separated from the anode by acidic electrolyte (Foller and Kelsall, 1993) and a spiral wound MEA-based cell (Nishiki et al., 2011). Foller and Kelsall reported a variation of the zero gap, or of the more standard acid electrolyte (Foller and Kelsall, 1993). This is a remarkable study for several reasons: (1) it was one of the first to employ an air breathing cathode (air depolarized) as in a fuel cell; (2) the maximum current efficiency obtained was $45 \%$ using a glassy carbon anode, albeit in highly concentrated (corrosive, expensive) $\mathrm{HBF}_{4}$ at $-5{ }^{\circ} \mathrm{C}$; (3) the paper presents a thoroughgoing analysis of the engineering aspects of the electrochemical reactors employed. One of the two reactors employed in the study utilized two air breathing cathodes between which were cooled, tubular glassy carbon electrodes immersed in the aqueous $\mathrm{HBF}_{4}$ electrolyte. The authors employed an air cathode following the work of the Permelec Electrode Corporation who incorporated such an air cathode into Membrel-type cell (Katoh et al., 1992) and obtained current efficiencies of $c a$. $16 \%$ at a cell voltage of 
ca. $2.3 \mathrm{~V}$. Other variations of the zero gap configuration include the work by Okada and Naya who employed a polyethylene terephthalate felt separator between the Nafion membrane and Pt mesh cathode in order to prevent degradation of the Nafion on the cathode side of the cell due to transport of Pt particles from the Pt mesh anode to the cathode (Okada and Naya, 2009). As the cathode was no longer in contact with the Nafion membrane, dilute $\mathrm{NaCl}$ or $\mathrm{Na}_{2} \mathrm{SO}_{4}$ was employed as the catholyte. The authors reported a current efficiency of $20 \%$ at room temperature; a remarkably high value for Pt.

Unfortunately, there are a number of challenges to be addressed when employing zero gap cells with air-breathing cathodes.

In terms of the decreased cell voltage, in practice, kinetic realities mean that the overpotentials (the extra driving force required over and above the potentials predicted on the basis of thermodynamics) at anode and cathode can reduce this advantage. For example, any practical electrolysis cell will operate with air, rather than pure oxygen, at the cathode hence decreasing the maximum rate of the cathode reaction and increasing its overpotential.

Katoh et al., 1994, highlight another problem associated with air breathing cathodes, which is that of flooding (Katoh et al., 1994). Water balance in such electrodes is crucial (Li et al., 2008) since water is produced at the cathode via the reverse of reaction (2); in addition, every proton drags between 1 and 5 water molecules with it as it passes through the polymer electrolyte membrane from anode to cathode (electro-osmotic drag (Li et al., 2008; Okada et al., 1998)). As a result, the pores of the cathode may become flooded with water, which blocks access to the oxygen gas and hence increases cell voltage (under constant current operation) or decreases current (under constant voltage operation). By employing a "water permeable, high performance gas diffusion" cathode, Katoh et al., reported that no flooding was observed, and the electrolyser operated at a current density of $1.0 \mathrm{~A} \mathrm{~cm}^{-2}$ and current efficiency of $16-17 \%$ for 85 days (Katoh et al., 1992). However, this is the only such report in the literature.

Less obvious from the electrochemical ozone literature is the very serious problem of calcification (Nishiki et al., 2011; Valdes and Moussy, 1999): multiply charged ions such as $\mathrm{Ca}^{2+}$ and $\mathrm{Mg}^{2+}$, which are present in hardwater, precipitate inside Nafion (probably near the cathode) as hydroxides and/or carbonates (Sawyer et al., 2002) causing a significant increase in membrane resistance and precluding the use of MEA-based cells to inject ozone directly into tapwater. Whilst the problem is mentioned 
explicitly by Nishiki et al. (Nishiki et al., 2011), and Valdes and Moussy (Valdes and Moussy, 1999), (the latter with respect to the use of Nafion in sensors for biological applications), and the use of “imitation" tapwater is reported by Kaneda et al. (Kaneda et al., 2005), and Awad et al. (Awad et al., 2006), the only indication that this is a serious problem is that all the other publications on MEA-based electrochemical ozone generation employ very low conductivity, de-ionised water and avoid using multiply charged cations where electrolyte is employed rather than electrolyte-free water.

Finally, the solubility of ozone in water depends upon pH (De Smedt et al., 2001; Levanov et al., 2008; Seidel, 2006), decreasing as $\mathrm{pH}$ increases. This can present additional problems when employing neutral anolytes as increased bubble formation at the electrode/Nafion interface has been postulated as having an adverse affect upon proton transfer into the Nafion membrane (Cui et al., 2009), increasing membrane resistance.

Presumably as a result of the challenges detailed above, by far most reports concern pure water and $\mathrm{H}_{2}$ cathodes (Arihara et al., 2006; Awad et al., 2006; Beaufils et al., 1999; Da Silva et al., 2010; Franco et al., 2008; Han et al., 2006; Kraft et al., 2006; Onda et al., 2005; Stucki et al., 1985; Tatapudi and Fenton, 1993), with only Katoh et al. (Katoh et al., 1994), and the Chan group (Cui et al., 2009; Wang et al., 2006) reporting work on electrochemical ozone generation in zero gap cells using air cathodes, the latter operating at significantly lower current densities $\left(\leq 60 \mathrm{~mA} \mathrm{~cm}{ }^{-2}\right)$ than the former due to limitations imposed by flooding (Chan and Christensen, 2011).

In general, electrochemical ozone generation is carried out either in single pass/flow operation (Cui et al., 2009), or in batch recycle mode (Stucki et al., 1985) in which the ozonated anolyte is returned to the electrochemical cell. In the former case, ozone is generated in both gas and liquid phases continuously; in the latter, once saturation of the anode solution has taken place, all the ozone produced is released into the gas phase. Under batch recycle operation, Stucki and co-workers employing $\mathrm{PbO}_{2}$ in an MEA-based, zero gap cell found that inlet ozone concentrations of $5-25 \mathrm{ppm}$ in de-ionised water had no effect on current efficiency (Stucki et al., 1985). In contrast, Christensen et al. (Christensen et al., 2009), have reported that the current efficiencies observed during operation under flow conditions were consistently higher (> 30\%) than those observed during batch recycle operation $(3-8 \%)$. The authors employed $\mathrm{Ni} / \mathrm{Sb}-\mathrm{SnO}_{2}$ anodes in a standard acid/acid cell, see fig. 4(b), and postulated that the presence of high concentrations of $\mathrm{O}_{3}$ in aqueous sulphuric acid inhibits the $\mathrm{O}_{3}$ 
evolution process at $\mathrm{Ni} / \mathrm{Sb}-\mathrm{SnO}_{2}$ anodes, possibly by replacing key adsorbed intermediates by adsorbed $\mathrm{O}_{3}$ (Christensen and Imkum, 2011).

\section{The effect of temperature on the electrochemical generation of ozone}

It was realised very early in the research on electrochemical ozone generation that low temperatures favoured higher ozone current efficiencies at Pt and Pt-based electrodes (Briner, 1937; Briner and Yalda, 1942; Lash et al., 1951; Putnam et al., 1948; Seader and Tobias, 1952), an observation later confirmed using other anode materials; e.g. $\mathrm{PbO}_{2}$ (Amadelli et al., 2000; Da Silva et al., 2001; Foller and Tobias, 1982) and carbon (Foller and Kelsall, 1993). However, some authors have reported that ozone efficiency at $\mathrm{PbO}_{2}$ decreases with decreasing temperature, (Da Silva et al., 2010; Velichenko et al., 2002). Early workers took great care to cool the anode as it was generally believed that the anode temperature, rather than that of the electrolyte, was critical (Foller and Tobias, 1982; Lash et al., 1951; Putnam et al., 1948; Seader and Tobias, 1952), and that gas bubbles could adversely affect heat transfer (Fischer and Bendixsohn, 1909; Fischer and Massenez, 1907; Foller and Tobias, 1982; Mazza et al., 1978; Seader and Tobias, 1952). Putnam and co-workers, Lash and co-worker, and Feng and coworkers have reported that the real effect of current density on $\mathrm{O}_{3}$ evolution is hidden by the secondary heating effect at higher current densities. Lash and co-workers deconvoluted the two effects by effective (internal) cooling of their PtIr tubular anode and were able to show a linear relationship between $\log$ (current density) and current efficiency (Feng et al., 1994; Lash et al., 1951; Putnam et al., 1948).

Briner et al., electrolysed a 5.0 $\mathrm{M} \mathrm{H}_{2} \mathrm{SO}_{4}$ eutectic solution using a $\mathrm{Pt}$ anode, obtaining a maximum current efficiency of $8.5 \%$ at $-67{ }^{\circ} \mathrm{C}$ (Briner, 1937). Putnam et al., obtained a maximum current efficiency of $19.4 \%$ by electrolysing a $30 \% \mathrm{HClO}_{4}$ solution at $-50{ }^{\circ} \mathrm{C}$ using a $\mathrm{Pt}$ anode; however, they found significantly lower efficiencies using $\mathrm{H}_{2} \mathrm{SO}_{4}$ at temperatures down to $-62{ }^{\circ} \mathrm{C}$, in contrast to the results reported by Briner and co-workers (Putnam et al., 1948). Interestingly, Putnam et al., analysed the ozone evolved from their cells by liquefaction and measurement of the boiling point; an interesting risk assessment to perform under current health and safety strictures (Putnam et al., 1948).

In general, ozone efficiency falls dramatically as the temperature approaches room temperature when Pt anodes are employed (Balej and Thumova, 1974; Putnam et al., 1948; Seader and Tobias, 1952), and

the primary effect of increasing temperature on electrochemical ozone generation is generally accepted 
to be to increase the decomposition of $\mathrm{O}_{3}$, at least at Pt anodes; this was first postulated by Fisher and co-workers in 1907 (Fischer and Bendixsohn, 1909; Fischer and Massenez, 1907). In more recent papers and reviews of electrochemical ozone generation at a variety of anodes, this theory has remained unchallenged (Babak et al., 1994; Da Silva et al., 2001, 2003a; Da Silva et al., 2006; Da Silva et al., 2003b; Feng et al., 1994; Foller and Tobias, 1982; Franco et al., 2008; Kim and Korshin, 2008; Stucki et al., 1987).

\section{The anode material}

The anodes employed for electrochemical generation fall into two time periods: $\leq 1982$ and $>1982$. Up to 1982 , the only anode materials that had been investigated were $\mathrm{Pt}$ and $\mathrm{PbO}_{2}$ ((Foller and Tobias, 1982) and references therein), and then only in aqueous acid electrolytes. After 1982, Pt ceased to be of interest (with one exception, see (Okada and Naya, 2009)) presumably due to the poor current efficiencies observed near room temperature when compared with, for example, $\mathrm{PbO}_{2}$. Whilst $\beta-\mathrm{PbO}_{2}$ continues to be researched with respect to electrochemical ozone generation (see, for example, (Awad and Saleh, 2010; Da Silva et al., 2010)) alternative materials have been investigated, including glassy carbon (Foller and Kelsall, 1993), Ni/Sb-SnO $\mathrm{Sn}_{2}$ (Wang et al., 2005), $\mathrm{IrO}_{2}-\mathrm{Nb}_{2} \mathrm{O}_{5}$ (Santana et al., 2004, 2005), tantalum oxide (Kaneda et al., 2006; Kaneda et al., 2005), $\mathrm{TiO}_{2}$ (Graves et al., 1992; Kitsuka et al., 2009, 2010) and Boron Doped Diamond (BDD) (Arihara et al., 2006; Arihara et al., 2007; Katsuki et al., 1998; Kraft et al., 2006; Michaud et al., 2003; Nishiki et al., 2011).

It is generally accepted that the most active of the $\alpha$ and $\beta$ forms of $\mathrm{PbO}_{2}$ is the latter ( $\mathrm{Da}$ Silva et al., 2001). A comparison of ozone evolution at $0{ }^{\circ} \mathrm{C}$ at $\mathrm{PbO}_{2}$ anodes gives a fairly accurate view of the general activity of this material. In the absence of added $\mathrm{F}^{-}$or fluoride-containing electrolytes, the current efficiencies observed at $\mathrm{PbO}_{2}$ are ca. 3 - $10 \%$ at current densities of ca. $1.0 \mathrm{~A} \mathrm{~cm}^{-2}$ in aqueous $\mathrm{H}_{2} \mathrm{SO}_{4}$ or $\mathrm{HClO}_{4}$ (Da Silva et al., 2006; Da Silva et al., 2003b; Foller and Tobias, 1982; Kotz and Stucki, 1987).Addition of NaF increased current efficiency to 21\% (Kotz and Stucki, 1987) or 10\% (Da Silva et al., 2003a), and in 7.3 $\mathrm{M} \mathrm{HPF}_{6}$, an efficiency of ca. $50 \%$ was observed at $-65^{\circ} \mathrm{C}$ by Foller and Tobias (Foller and Tobias, 1982),

$\mathrm{IrO}_{2}-\mathrm{Nb}_{2} \mathrm{O}_{5}$ shows a very low ozone current efficiency at $0{ }^{\circ} \mathrm{C}$ in $3.0 \mathrm{M} \mathrm{H}_{2} \mathrm{SO}_{4}, c a$. $1 \%$, rising to $c a$. $12 \%$ at $800 \mathrm{~mA} \mathrm{~cm}^{-2}$ in the presence of $0.03 \mathrm{M} \mathrm{KPF}_{6}$ (Santana et al., 2004). Using a layered anode formed on $\mathrm{Si}$ and exposing $\mathrm{TiO}_{2}$ to the $0.01 \mathrm{M} \mathrm{HClO}_{4}$ solution, Kitsuka et al. have reported a current 
efficiency of ca. $9 \%$ at $50 \mathrm{~mA} \mathrm{~cm}$ and $15{ }^{\circ} \mathrm{C}$ (Kitsuka et al., 2010). Tantalum oxide-based anodes have shown a current efficiency of $c a .12 \%$ at room temperature and $200 \mathrm{~mA} \mathrm{~cm} \mathrm{~cm}^{-2}$ using model tap water at neutral $\mathrm{pH}$.

Boron doped diamond electrodes remain something of an enigma in the field of electrochemical ozone generation in that it is not entirely clear that they can be expected to generate ozone routinely. Typically, BDD electrodes are grown on suitable substrates (Ti, Ta, Mo, glassy carbon and, most generally, Si) by chemical vapour deposition, doping with boron decreases the resistivity of the semiconducting diamond, with $\mathrm{ca} \cdot 10^{20}-10^{21} \mathrm{~B}$ atoms $\mathrm{cm}^{-3}$ giving a resistivity of ca. $10^{-3} \Omega \mathrm{cm}$ (Panizza and Cerisola, 2005). BDD anodes show high anodic stability and a wide potential window for water discharge (high overpotentials for water reduction and oxidation); they are regarded as essentially inert and with poor adsorptive qualities such that electron transfer takes place via outer sphere reactions (Panizza and Cerisola, 2005). In terms of water treatment, rather than as ozonegenerating anodes, BDD electrodes are generally regarded as oxidizing organic molecules by direct electron transfer at potentials below oxygen evolution and indirectly via $\mathrm{OH}$ radicals at higher potentials (Kapalka et al., 2009; Panizza and Cerisola, 2005), produced via the primary water discharge reaction (Kotz and Stucki, 1987; Marselli et al., 2003; Martinez-Huitle and Brillas, 2009). The number of papers reporting $\mathrm{O}_{3}$ generation is relatively few (see, for example, (Arihara et al., 2006; Arihara et al., 2007; Katsuki et al., 1998; Kraft et al., 2006; Michaud et al., 2003; Nishiki et al., 2011)) compared to the very large number of papers on direct/indirect combustion (see, for example, (Balej and Thumova, 1974), and the extensive work by Ch. Comninellis and co-workers (Kapalka et al., 2009) and references therein). Michaud and co-workers report that the main product of water electrolysis in $\mathrm{H}_{2} \mathrm{SO}_{4}$ is peroxydisulfate $\left(\mathrm{S}_{2} \mathrm{O}_{8}{ }^{2-}\right)$, and in $\mathrm{HClO}_{4}$ it is oxygen (Michaud et al., 2000; Michaud et al., 2003). Both Katsuki et al. (Katsuki et al., 1998), and Michaud et al. (Michaud et al., 2003), report ozone current efficiencies of a "few percent" electrolyzing aqueous acid in divided cells. In contrast, Kraft et al. (Kraft et al., 2006), Arihara et al. (Arihara et al., 2006; Arihara et al., 2007), electrolyzed de-ionized water $\left(<1 \mu \mathrm{S} \mathrm{cm}^{-1}\right)$ using zero gap cells with Nafion membranes and obtained maximum current efficiencies of $24 \%$ and $47 \%$, respectively. Given the small number of papers to consider, the drawing of detailed conclusions is of questionable validity, but it may be that anion adsorption disfavours the production of ozone at BDD anodes, eg. by inhibiting reactions (11) and/or (16) above via interference of anions in the encounters between active oxygen species (Arihara et al., 2006). The exception to this postulate is the work reported by Nishiki et al., who observed a relatively low current efficiency in "pure" (source unspecified by the authors) water (13\%) as well as in tapwater containing 
calcium and magnesium salts $(6 \%)$; however, this work is unusual for several reasons and hence is dealt with in detail below (Nishiki et al., 2011).

Kraft et al. (Kraft et al., 2006), employed BDD-coated niobium expanded metal electrodes (29 mm x $45 \mathrm{~mm}$ ) as anode and cathode, pressed either side of a Nafion membrane positioned in a pipe flowthrough reactor, with only the solution ozone being monitored photometrically by the indigo method (Bader and Hoigne, 1981). Higher flow rates gave higher current efficiencies, the maximum efficiency of $24 \%$ being observed at a flow rate of $40 \mathrm{dm}^{3} \mathrm{hr}^{-1}$ and $115 \mathrm{~mA} \mathrm{~cm}$; this was attributed to more ozone being entrained at higher flow rates, as well as cooling effects reducing the thermal decay of $\mathrm{O}_{3}$ (as usual with BDD electrodes, high cell voltages were required, eg. $23 \mathrm{~V}$ at $383 \mathrm{~mA} \mathrm{~cm}^{-2}$, leading to the very real possibility of local heating effects). Increasing the conductivity of the anolyte feed was found to cause a marked drop in ozone current efficiency, eg. at a flow rate of $10 \mathrm{dm}^{3} \mathrm{hr}^{-1}$ and $77 \mathrm{~mA}$ $\mathrm{cm}^{-2}$, the current efficiency dropped to ca. $2 \%$ when the conductivity was increased from 1 to $2000 \mu \mathrm{S}$ $\mathrm{cm}^{-1}$, ie comparable to the efficiencies observed by Michaud et al. (Michaud et al., 2003) and Katsuki et al. (Katsuki et al., 1998), in their studies employing acid electrolytes. This was attributed by the authors to more of the BDD surface becoming electrochemically active as the conductivity of the anolyte increased, and hence the real current density decreasing.

Arihara and co-workers have reported the generation of ozone at $50 \mathrm{~mm}$ x $15 \mathrm{~mm}$ × $2 \mathrm{~mm}$ freestanding, perforated BDD plate anodes, see fig. 6 (Arihara et al., 2006; Arihara et al., 2007). The BDD anode and Pt mesh cathode were pressed either side of a Nafion membrane. Deionised water $(<1 \mu \mathrm{S}$ $\mathrm{cm}^{-1}$ ) was employed as the catholyte and anolyte, with the ozone being monitored only in the solution phase by spectrophotometry. At an anolyte flow rate of $2 \mathrm{dm}^{3} \mathrm{~min}^{-1}$, anolyte temperature of $12{ }^{\circ} \mathrm{C}$ and $530 \mathrm{~mA} \mathrm{~cm}{ }^{-2}$, the authors reported an optimum current efficiency of $47 \%$, a very significant achievement. However, the cost in terms of energy usage was high since cell voltages of $22-24 \mathrm{~V}$ were required, equating to $175 \mathrm{kWh}$ per $\mathrm{kg} \mathrm{O}_{3}$ at $530 \mathrm{~mA} \mathrm{~cm}$; this does not compare well with the standard method of generating ozone, cold corona discharge, the optimum energy consumption of such systems is often quoted as being between 13 and $29 \mathrm{kWh} \mathrm{kg}^{-1}$ (Seidel, 2006), or even as low as $8 \mathrm{kWh}$ $\mathrm{kg}^{-1}$ (Rau, 2009), a fact the authors themselves highlight. At higher current densities, the efficiency was found to decrease; the authors interpreted this in terms of more partition of ozone into the gas phase, increased autolysis due to the increased solution concentration and an increase in side reactions 
such as the production of hydrogen peroxide. The latter has been reported as increasing the decay of ozone, catalysed by glass reactor walls (Sehested et al., 1998), due to reactions such as:

$$
\mathrm{H}_{2} \mathrm{O}_{2}+\mathrm{O}_{3} \rightarrow \mathrm{HO}+\mathrm{HO}_{2}+2 \mathrm{O}_{2}
$$

Nishiki and colleagues employed a $40 \mathrm{~mm}$ long, $2 \mathrm{~mm}$ diameter BDD rod anode, wrapped in Nafion strips over which was coiled a stainless steel wire cathode, see fig. 7; this was mounted inside a $4 \mathrm{~mm}$ inside diameter tube to form a flow cell (Nishiki et al., 2011). Presumably, the anolyte contacts the BDD/Nafion water interface at the edges of the strips (which are not presented as wound so as to completely cover the BDD rod) or the ozone is generated at the BDD/Nafion interface directly below the wire counter electrode (as would be expected on the basis of electric field considerations) then diffuses through the Nafion to the Nafion/water interface. However the latter process would enhance the expected dehydration of the BDD/Nafion interface due to water discharge and the electro-osmotic effect (Li et al., 2008; Okada et al., 1998). In any case, the actual active area of the anode was unclear. It appeared that the ozone + oxygen generated at the anode and hydrogen generated at the cathode were allowed to mix; again, this was not explicitly stated. The authors employed tapwater (Fujisawa City, total hardness $70 \mathrm{mg} / \mathrm{L}$, chloride concentration $10 \mathrm{mg} / \mathrm{L}$ ), and tapwater with added $\mathrm{Ca}^{2+}$ (as $\mathrm{CaCl}_{2}$, to assess the effect of hardness) or $\mathrm{Cl}^{-}$(as $\mathrm{NaCl}$ ); they also used 'pure' water, but the source and composition of this was not specified. The calcification of the membrane was assessed by the mass change after 2 hours electrolysis, with no mass change being observed in the case of pure water. In tap water, at a constant current of $0.8 \mathrm{~A}$ and cell voltage of $16 \mathrm{~V}$, the authors observed a current efficiency of $2.5 \%$; under the same conditions, "pure" water gave $8 \%$ current efficiency at $10 \mathrm{~V}$. The cell voltage increased from ca. $3 \mathrm{~V}$ at $0.2 \mathrm{~A}$ to $16 \mathrm{~V}$ at $0.8 \mathrm{~A}$.

The authors found that the current efficiency was lower in the more conducting tapwater than in pure water, see table 1 , which shows data obtained as a function of flow rate at $0.75 \mathrm{~A}$. This was attributed to two primary effects: (1) more of the BDD electrode becoming electroactive band hence a decrease in current density, as was postulated by Arihara et al. (Arihara et al., 2006; Arihara et al., 2007), and (2) competition from the generation of chlorine-containing products via the oxidation of chloride ions. The latter was supported by UV Vis data.

Figure 8 shows the variation in cell voltage and solution ozone concentration observed by Nishiki et al. (Nishiki et al., 2011), as a function of hardness (as added $\mathrm{CaCl}_{2}$, although the exact definition of 
hardness as $\mathrm{mg} / \mathrm{L}$ was not specified by the authors, nor was the flow rate specified). The cell voltage increased very little with hardness (albeit already high at $12-15 \mathrm{~V}$ ); however, the membrane was found to increase in mass following 2 hours electrolysis at 1A, see fig. 9. The mass gain, due to calcification, was found to decrease as flow rate increased, attributed by the authors to physical removal of the deposit. Interestingly, when the cell was operated with the current on for 8 minutes and off for 2 minutes, a marked decrease in calcification was observed, see fig. 9; the authors postulated that this was due to the cathode $\mathrm{pH}$ decreasing back to neutral during the 'off' periods and facilitating dissolution of the scale. Durability studies over 250 hours electrolysis under constant and interrupted current conditions supported the benefits of on/off operation, with the ozone current efficiency remaining constant at around 3\% under current interrupt operation, whereas it fell steadily to $<1 \%$ at constant current.

The high cell voltage and low current results in a very high energy cost, eg. $1675 \mathrm{kWh} \mathrm{kg}^{-1} \mathrm{O}_{3}$ under current interrupt operation. Nevertheless, the authors believe the system to have real application, and reported data on the disinfection of water inoculated with Pseudomonas aeruginosa, Escherichia coli, and Staphylococcus epidermidis. They also employed the cell to treat 43 dogs and 10 cats suffering from Superficial Pyoderma and Seborrhea.

There are only two anode materials that have been reported as generating ozone at current efficiencies $>20 \%$, temperatures $>0{ }^{\circ} \mathrm{C}$ and in water, or water with non-fluoride electrolyte; the first is BDD (see above) and the second is $\mathrm{Ni} / \mathrm{Sb}-\mathrm{SnO}_{2}$. In 2004, Prof. K. Y. Chan of Hong Kong University (Cheng and Chan, 2004) reported (incorrectly) that his group had generated ozone from $0.64 \mathrm{~cm}^{2} \mathrm{Sb}-\mathrm{SnO}_{2} \mathrm{Ti}$ foil electrode in $0.1 \mathrm{M} \mathrm{HClO}_{4}$ in a UV-Vis cuvette electrochemical cell, see fig 10, with a maximum current efficiency of $15 \%$ at cell voltages $<3 \mathrm{~V}$. In a second paper (Wang et al., 2005) it was reported that the activity of the anodes reported in the first publication was due to adventitious Ni. This latter paper detailed the preparation of $\mathrm{Ni} / \mathrm{Sb}-\mathrm{SnO}_{2}$ electrodes and reported a maximum current efficiency of $35 \%$, again using the UV-Vis cuvette cell. There had been one previous report of ozone generation at $\mathrm{Sb}-\mathrm{SnO}_{2} / \mathrm{Ti}$ mesh by Foller and Tobias (Foller and Tobias, 1982); the authors reported a maximum current efficiency of ca. $4 \%$ in $5.0 \mathrm{M} \mathrm{H}_{2} \mathrm{SO}_{4}$ at $0{ }^{\circ} \mathrm{C}$, which was short lived, due to dissolution of the electrode. Otherwise, $\mathrm{Sb}-\mathrm{SnO}_{2}$ electrodes are generally considered not to be ozone active. In general, $\mathrm{Sb}-\mathrm{SnO}_{2}$ anodes supported on $\mathrm{Ti}$ are associated with the direct, electrochemical oxidation of organics (Martinez-Huitle and Brillas, 2009). Hence, the production of very high $\mathrm{O}_{3}$ activity at low cell voltages under ambient conditions and in a simple electrolyte through the addition of small amounts of Ni to Sb- 
$\mathrm{SnO}_{2}$ is truly remarkable, and could not have been predicted. In a later paper, Christensen et al. (Christensen et al., 2009), reported current efficiencies up to $50 \%$ (equivalent to $18 \mathrm{kWh} \mathrm{kg}^{-1} \mathrm{O}_{3}$ ) employing $\mathrm{Ni} / \mathrm{Sb}-\mathrm{SnO}_{2}$ anodes with platinised $\mathrm{Ti}$ mesh cathodes in a divided glass cell utilizing a Nafion membrane separator and $0.5 \mathrm{M} \mathrm{H}_{2} \mathrm{SO}_{4}$ as the electrolyte. The Christensen group (Christensen and Imkum, 2011; Christensen et al., 2012) have continued to report studies on $\mathrm{Ni} / \mathrm{Sb}-\mathrm{SnO}_{2}$ electrodes which seek to gain insights into the mechanism of ozone evolution at these anodes.

In 2006, the Hong Kong group reported the electrochemical generation of ozone in deionised water employing an MEA-based cell with static anolyte and Pt/porous carbon air breathing cathode (Wang et al., 2006). The anode comprised $\mathrm{Ni} / \mathrm{Sb}-\mathrm{SnO}_{2}$ coated on a $6 \mathrm{~cm}$ x $4 \mathrm{~cm}$ Ti mesh, and the cathode was operated ion 'passive' mode, ie. without pumping air past it. A maximum current efficiency of $15 \%$ was observed at a cell voltage of $2.0 \mathrm{~V}$, whilst the lowest energy consumption was $48 \mathrm{kWh} \mathrm{kg}^{-1}$, also at $2.0 \mathrm{~V}$, and $17 \mathrm{~mA} \mathrm{~cm}^{-2}$. The current density being limited principally by cathode flooding.

In a later paper (Cui et al., 2009) the Hong Kong group reported data on a scaled up cell and 4 cell stack. The anodes were $\mathrm{Ni} / \mathrm{Sb}-\mathrm{SnO}_{2}$ coated Ti mesh $(8 \mathrm{~cm}$ x $13 \mathrm{~cm})$, and the cell \& stack operated in both passive and forced airflow $\left(10 \mathrm{dm}^{3} \mathrm{~min}^{-1}\right)$. The single cell, 4 cell stack and balance of plant are shown in figs $11(\mathrm{a})-(\mathrm{c})$, respectively. Deionised water $(18.2 \mathrm{M} \Omega \mathrm{cm})$ was fed to the anode(s) at flow rates from 0.2 to $4.0 \mathrm{dm}^{3} \mathrm{~min}^{-1}$ (linear velocities from 0.52 to $10.42 \mathrm{~cm} \mathrm{~s}^{-1}$ ). Ozone was monitored using a flow cell linked by fibre optic cables to a spectrophotometer. Typical spectra so obtained are shown in fig. 12; as may be seen, the peak due to ozone $\left(\lambda_{\max }=258 \mathrm{~nm}\right)$ was superimposed upon a significant baseline offset and an underlying absorption having a peak $<250 \mathrm{~nm}$. The baseline offset was attributed to bubbles scattering the incident light; Arihara et al. (Arihara et al., 2007), observed the same problem and employed a reservoir before the UV Vis cell in order to allow gas release. The authors did not discuss the underlying absorption, and it is not possible from the data presented in the paper to identify if the absorption showed a maximum. However, as stated above, $\mathrm{H}_{2} \mathrm{O}_{2}$ is an expected side product of electrochemical ozone generation, and has an absorption from ca. $350 \mathrm{~nm}$ with no maximum above 200 nm (Christensen and Imkum, 2011; Holt et al., 1948; Phibbs and Giguere, 1951).

The current densities employed by the authors $\left(<60 \mathrm{~mA} \mathrm{~cm}{ }^{-2}\right)$ were again limited by flooding (Chan and Christensen, 2011), with cell voltages between $3 \mathrm{~V}$ and $6 \mathrm{~V}$ for the single cell. The four cell stack gave a maximum current efficiency of $c a .22 \%$ at an anolyte flow rate of $5.9 \mathrm{dm}^{3} \mathrm{~min}^{-1}, 29.8 \mathrm{~mA} \mathrm{~cm}$ 
and 3.0V; the lowest energy consumption was $42 \mathrm{kWh} \mathrm{kg}^{-1} \mathrm{O}_{3}$ at $24.3 \mathrm{~mA} \mathrm{~cm}^{-2}$ and $5.4 \mathrm{dm}^{3} \mathrm{~min}^{-1}$. The energy requirement is the lowest of MEA-based cells (injecting ozone directly into water and either air breathing or hydrogen evolving), thus: Katoh and co-workers (Katoh et al., 1994) (maximum current efficiency $19 \%, \mathrm{PbO}_{2}$ anode) obtained an energy requirement of $40-50 \mathrm{kWh} \mathrm{kg}^{-1} \mathrm{O}_{3}$ (pure oxygen feed) or $60-80 \mathrm{kWh} \mathrm{kg}^{-1} \mathrm{O}_{3}$ (hydrogen evolved), Stucki and co-workers using the commercial Membrel electrolyser (20\% maximum current efficiency, $\mathrm{PbO}_{2}$ anode, commercial since the early 1980's, hydrogen evolving; (Stucki et al., 1987)) obtained an energy requirement of $65 \mathrm{kWh} \mathrm{kg}^{-1} \mathrm{O}_{3}$; more recently, Da Silva and co-workers (Da Silva et al., 2010), reported an energy requirement of 70 kWh kg-1 (13\% efficiency, $\mathrm{PbO}_{2}$ anode, $\mathrm{H}_{2}$ evolving cathode). In contrast, Arihara and co-workers (Arihara et al., 2007) obtained an energy cost of $140 \mathrm{kWh} \mathrm{kg}^{-1} \mathrm{O}_{3}$ at the maximum current efficiency of $47 \%$, reflecting the significantly higher cell voltages required when using BDD anodes. In general, $\mathrm{PbO}_{2}$ and BDD systems operate at current densities of $c a .1 \mathrm{~A} \mathrm{~cm}{ }^{-2}$; in contrast, $\mathrm{Ni} / \mathrm{Sb}-\mathrm{SnO}_{2}-$ based systems operate at $<100 \mathrm{~mA} \mathrm{~cm}{ }^{-2}$; hence the latter generate less $\mathrm{O}_{3}$ per $\mathrm{cm}^{2}$ than the former two.

\section{The effect of current density}

In general, at $\mathrm{PbO}_{2}$ anodes, current efficiency increases essentially linearly with current density (Feng et al., 1994) before levelling out and becoming independent (Beaufils et al., 1999; Da Silva et al., 2010; Foller and Tobias, 1982; Han et al., 2006; Stucki et al., 1987; Tatapudi and Fenton, 1993); typically, the current density at which this change occurs is $c a .1 .0 \mathrm{~A} \mathrm{~cm}^{-2}$, but this value depends upon the electrolyte composition (Foller and Tobias, 1982). Exceptions to this observation are Onda and coworkers (Onda et al., 2005) and Awad and co-workers (Awad and Saleh, 2010), both groups observe current efficiency to go through a maximum, at around $1.0 \mathrm{~A} \mathrm{~cm}^{-2}$ and $1.5-2.0 \mathrm{~mA} \mathrm{~cm}^{-2}$ (respectively), before decreasing.

Boron doped diamond anodes show similar behaviour to $\mathrm{PbO}_{2}$, with current efficiency becoming independent of current density (Arihara et al., 2007) or showing a clear maximum (Kraft et al., 2006). $\mathrm{TiO}_{2}$ (Kitsuka et al., 2009, 2010), Pt (Seader and Tobias, 1952), C (Foller and Kelsall, 1993) and $\mathrm{TaO}_{\mathrm{x}}$ (Kaneda et al., 2006; Kaneda et al., 2005) show increasing current with current density; however, this may simply reflect the fact that, should the current density have been increased beyond the maximum employed by these workers, a leveling out or decrease in current efficiency may have been observed. $\mathrm{IrO}_{2}-\mathrm{Nb}_{2} \mathrm{O}_{5}$ shows an onset current density for ozone evolution that varies with $\mathrm{IrO}_{2}$ content (Santana et al., 2004). Ni/Sb-SnO 2 electrodes show a clear maximum (Wang et al., 2006; Wang et al., 2005). 
When employing zero gap cells with low conductivity (eg. de-ionised) water as the anolyte, the active area of the anode is significantly less than its geometric area, since the former will be only that region of the anode at the boundary with water and the Nafion membrane. Hence, the actual current density will be higher than that calculated on the basis of the geometric area (Kraft et al., 2006); one consequence of this is that, if the conductivity of the anolyte is increased, current efficiency decreases due to the decrease in current density as more of the anode becomes active (Arihara et al., 2006; Foller and Kelsall, 1993; Kraft et al., 2006).

To our knowledge, there are no reports in the literature in which current efficiency vs current density data are modeled on the basis of a detailed, mechanistic framework.

\section{The effect of electrolyte}

As it is generally believed that ozone efficiency increases with decreasing pH (Da Silva et al., 2006; Seidel, 2006; Wang et al., 2005), most of the papers in the electrochemical ozone literature concern ozone generation using either aqueous acid electrolytes or, to a lesser extent, using Nafion as an (acidic) polymer electrolyte membrane, (Nafion is also commonly employed as the cell separator in the studies using acidic electrolytes). There are a few studies on the effect of the anion on ozone efficiency in acid solution. By far the most comprehensive work on this was reported by Foller and Tobias in 1982 (Foller and Tobias, 1982). The authors found a linear relationship between ozone current efficiency in $2.0 \mathrm{M}$ acid at $0{ }^{\circ} \mathrm{C}$ using $\beta-\mathrm{PbO}_{2}$ anode and the "composite electronegativity" of the anions. The composite electronegativity was obtained by summing the tabulated electronegativities of the individual atoms of the anion. The data were rationalised essentially in terms of a model similar to that elucidated above (see (10) - (17)), in which one of the active intermediates in the formation of $\mathrm{O}_{3}$ is the adsorbed oxygen atom. Quite simply, anion and oxygen coverage are competitive, with the former determined by the electronegativity of the anion: the more electronegative the less adsorption takes place. Thus, at high anion coverage, the free energy of adsorption of $\mathrm{O}^{\circ}$ is too low and the activation energy for $\mathrm{O}_{\mathrm{a}}+\mathrm{O}_{\mathrm{a}} \rightarrow \mathrm{O}_{2}$ is so low that $\mathrm{O}_{3}$ does not have time to form. Conversely, too little anion adsorption causes the $\mathrm{O}$ atoms to be bound too tightly. However, the authors also commented that, due to the evolution of gas, the free energy of adsorption of the $\mathrm{O}$ atom would actually assume a broad range of values. An ideal anion coverage, specific for a particular electrolyte and anode material, would then produce the maximum possible ozone efficiency for that combination. Anions such as $\mathrm{F}^{-}$that are non-adsorbing may never show such a maximum in efficiency as 'optimum' surface 
coverage is never reached. The authors also postulated that $\mathrm{F}^{-}$could inhibit the discharge of water (to $\mathrm{O}_{2}$ ) by hydrogen bonding to the $\mathrm{H}$ atoms of water in the Inner Helmholtz Layer.

There does not appear to be any detailed later studies on the general effect of anion adsorption on electrochemical ozone generation in acid solution; studies in acid electrolyte focus primarily on the effect of $\mathrm{F}^{-}$or F-containing electrolytes e.g. (Da Silva et al., 2001, 2003a; Da Silva et al., 2003b; Kotz and Stucki, 1987; Santana et al., 2004). Da Silva and co-workers re-iterate the postulate of Foller and Tobias that $\mathrm{F}^{-}$stabilises the coverage of adsorbed oxygen atoms as well as inhibiting the oxygen evolution reaction (Da Silva et al., 2003a; Foller and Tobias, 1982).

With respect to the effect of common acid electrolytes on ozone current efficiency, this appears, as expected, to depend upon the anode material, thus Franco et al. (Franco et al., 2006), found that the ozone current efficiency at a $\beta-\mathrm{PbO}_{2}$ anode was $3.5 \%$ in $6.0 \mathrm{M} \mathrm{HClO}_{4}$ compared to $2.9 \%$ in $3.0 \mathrm{M}$ $\mathrm{H}_{2} \mathrm{SO}_{4}$. Y. H. Wang et al. (Wang et al., 2005), observed a current efficiency of ca. 35\% in $0.1 \mathrm{M} \mathrm{H}_{2} \mathrm{SO}_{4}$ and $c a .32 \%$ in $0.1 \mathrm{M} \mathrm{HClO}_{4}$ at a Ni/Sb-SnO 2 anode. At $-50{ }^{\circ} \mathrm{C}$ at a $\mathrm{Pt}$ anode, (Putnam et al., 1948), the current efficiency was ca. $20 \%$ in $30 \% \mathrm{HClO}_{4}$ and ca. $6 \%$ in $28 \% \mathrm{H}_{2} \mathrm{SO}_{4}$. However, Kötz and Stucki, observed a complex dependence of ozone efficiency at $1 \mathrm{~A} \mathrm{~cm}^{-2}$ when using $3.0 \mathrm{M} \mathrm{HClO}_{4}, \mathrm{H}_{2} \mathrm{SO}_{4}$ and $\mathrm{H}_{3} \mathrm{PO}_{4}$ as a function of temperature (Kotz and Stucki, 1987). Ozone efficiency at fixed current density generally goes through a maximum as the concentration of the acid electrolyte is increased (Foller and Tobias, 1982; Wang et al., 2005).

A number of studies have been reported using aqueous electrolytes at near neutral $\mathrm{pH}$ (Bader and Hoigne, 1981; Cui et al., 2009; Feng et al., 1994; Martinez-Huitle and Brillas, 2009; Michaud et al., 2000; Rau, 2009; Tatapudi and Fenton, 1994) with ozone current efficiencies of 5-12\%, including work using imitation tap water, aimed at the potential application of electrochemical ozone generation in water treatment (Arihara et al., 2006; Kaneda et al., 2005). Feng et al., obtained ozone current efficiencies of $6 \%$ and $c a .14 \%$ using $\beta-\mathrm{PbO}_{2}$ anodes without and with Fe doping, respectively, in $\mathrm{pH}$ 7.5 phosphate buffer at $10{ }^{\circ} \mathrm{C}$ (Feng et al., 1994). El-Shal et al., observed a maximum current efficiency of $7 \%$ at $\mathrm{PbO}_{2}$ in $\mathrm{pH} 7$ phosphate buffer (Elshal et al., 1994). Kaneda and co-workers have studied anodes based on tantalum oxide in imitation tap water, i.e. Millipore water containing added $\mathrm{Na}^{+}, \mathrm{Ca}^{2+}, \mathrm{K}^{+}$and $\mathrm{Mg}^{2+}$ salts to a conductivity of $160 \mu \mathrm{sm}^{-1}$ (Arihara et al., 2006; Kaneda et al., 2005). The authors observed a maximum ozone current efficiency of $c a$. $12 \%$, comparable to that 
observed by Feng et al. using Fe-doped $\beta-\mathrm{PbO}_{2}$ (Feng et al., 1994). To date, there have been no attempts to discuss the implications of such high ozone efficiencies obtained in neutral solution.

Low temperatures are often employed in conjunction with fluorine-containing anions to obtain high ozone current efficiencies (Babak et al., 1994; Foller and Tobias, 1982; Kotz and Stucki, 1987; Santana et al., 2005); as was stated above, this is generally believed to be due to the ability of small amounts of $\mathrm{F}^{-}$to raise the oxygen overpotential (Foller and Tobias, 1982) and was first reported in 1950 by A. Hickling and S. Hill (Hickling and Hill, 1950), although it has also been postulated that $\mathrm{F}^{-}$stabilises the coverage of singlet oxygen at $\mathrm{PbO}_{2}$, enhancing the production of $\mathrm{O}_{3}$ (Da Silva et al., 2003a). Thus, $\mathrm{PbO}_{2}$ at $0{ }^{\circ} \mathrm{C}$ typically exhibits current efficiencies of $10-12 \%$ in the absence of specialist anions, this increases up to $\mathrm{ca} .20 \%$ in the presence of $\mathrm{PF}_{6}^{-}$at the same temperature (Foller and Tobias, 1982). Foller and Kelsall reported a current efficiency of $45 \%$ using glassy carbon electrodes at $-5{ }^{\circ} \mathrm{C}$ in 62 wt\% $\mathrm{HBF}_{4}$ (Foller and Kelsall, 1993); however, the very high concentration of $\mathrm{HBF}_{4}$ employed required that it was especially synthesised and also resulted in intermittent passivation of the electrode which could only be reversed by periodic switching to open circuit potential. $\mathrm{F}^{-}$-doping of $\mathrm{PbO}_{2}$ anodes to inhibit $\mathrm{O}_{2}$ evolution and hence improve ozone current efficiency has also been employed see, for example, the work by Amadelli et al. (Amadelli et al., 1999), who obtained a maximum current efficiency of $\mathrm{ca} .8 \%$ at $25^{\circ} \mathrm{C}$ in $1 \mathrm{M} \mathrm{H}_{2} \mathrm{SO}_{4}$, using $\mathrm{PbO}_{2}$ anodes formed by electroldeposition from solutions containing 0.01 $\mathrm{M} \mathrm{NaF}$. Higher $\mathrm{F}^{-}$concentrations in the electrodepostion solution caused the ozone efficiency to decrease, reaching $1 \%$ at $40 \mathrm{mM} \mathrm{NaF}$. The latter observation was interpreted by the authors as higher $\mathrm{F}^{-}$-doping of $\mathrm{PbO}_{2}$ facilitating the formation of persulfate ions at the expense of $\mathrm{O}_{3}$.

\section{Conclusions}

Whilst there is a generally-accepted mechanism for electrochemical ozone generation, it is generic and does not take into account the wide variation in behaviour observed across the range of ozone active anodes reported in the literature in terms of required current density, the requirement for a minimum current density or not, etc. In particular, the fact that the addition of a minute quantity of Ni to (essentially) ozone-inactive $\mathrm{Sb}-\mathrm{SnO}_{2}$ renders the latter significantly active and selective towards the electrochemical generation of ozone at low current densities strongly suggests that all ozone-active anodes are not the same. Furthermore, the 'generic' mechanism remains largely unproven; not surprising given the obvious challenges associated with obtaining kinetic (or indeed any) information from electrodes vigorously evolving gas. 
The early studies of electrochemical ozone generation were carried out at very low temperatures in corrosive and, in some cases, expensive electrolytes and primarily using Pt anodes. Later, and to date, the favoured anode material was $\mathrm{PbO}_{2}$ in more conventional, acidic electrolytes, at temperatures around $0{ }^{\circ} \mathrm{C}$. These materials require high current densities for high current efficiencies, typically ca. $1 \mathrm{~A} \mathrm{~cm}^{-2}$.

It is clear that very high ozone current efficiencies (around $20-50 \%$ ) can be routinely obtained at certain anodes; for example, the activities and selectivities of BDD anodes can be very high indeed, albeit at a very high energy cost. $\mathrm{Ni} / \mathrm{Sb}-\mathrm{SnO}_{2}$ anodes also show such high activities and selectivities but at much lower currents and cell voltages; the former is a disadvantage in terms of the amount of ozone generated per unit area of electrode, although the development of synthetic routes to particulate electrocatalysts that can be deposited directly onto Nafion (as is commonly employed in MEA's utilizing $\mathrm{PbO}_{2}$ ) may well ameliorate this problem.

The new ozone anodes thus offer great promise for the electrochemical approach, and the advantages of the electrochemical generation of ozone have been well-rehearsed in the literature (see, for example, (Christensen et al., 2009) and references therein). However, the ability to exploit probably the most useful advantage of electrochemical ozone generation, of direct injection into water as opposed to dissolving gas phase $\mathrm{O}_{3}$, remains elusive for two reasons. To inject ozone directly into water requires the use of MEA-based, zero gap cells; these naturally utilize either hydrogen-evolving or air breathing cathodes, and all currently employ Nafion as the polymer electrolyte membrane. The latter essentially precludes the application of such cells in the treatment of 'real' or softened waters; $\mathrm{Ca}^{2+}$ and $\mathrm{Mg}^{2+}$ in the former essentially block the membrane, and $\mathrm{Na}^{+}$ions in the latter replace protons as the mobile species in the Nafion, move more slowly and increase resistance across the cell. This may be overcome by the development of membranes that can reject multiply-charged cations; for example Trogadas et al. (Trogadas et al., 2012), have reported that incorporating $\mathrm{SiO}_{2}$ into Nafion slows down the crossover of $\mathrm{V}^{3+}$ and $\mathrm{V}^{4+}$ ions. However, the flooding of air-breathing cathodes appears to limit the current densities accessible to commercially non-viable values, whilst hydrogenevolving cathodes will only be applicable for larger applications where the hydrogen can be utilized and is not a safety issue.

The stability of anodes such as $\mathrm{PbO}_{2}$ was regarded as a problem (Wen and Chang, 1993), as was that of BDD anodes (Panizza and Cerisola, 2005) but the plethora of available commercial electrochemical ozone generation systems based on these materials seems to mitigate against this; however, the toxicity 
of lead continues to be a barrier to its application in potable water treatment. The stability of $\mathrm{Ni} / \mathrm{Sb}$ $\mathrm{SnO}_{2}$ remains to be clarified.

\section{ACKNOWLEDGEMENTS}

KZ would like to thank Damascus University, Syria, for sponsorship and TY would like to thank Uludă̆ Universitesi for funding. 


\begin{tabular}{|c|c|c|c|}
\hline Source & 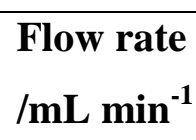 & $\begin{array}{l}\text { Current efficiency } \\
/ \%\end{array}$ & $\begin{array}{l}\mathrm{O}_{3} \text { concentration } \\
/ \mathrm{mg} \mathrm{L}^{-1}\end{array}$ \\
\hline \multirow[t]{3}{*}{ Pure water } & 40 & 7 & 6 \\
\hline & 250 & 10 & 2.5 \\
\hline & 400 & 13 & 1 \\
\hline \multirow[t]{3}{*}{ Tap water } & 40 & 2.5 & 2 \\
\hline & 150 & 4.5 & 1 \\
\hline & 400 & 6 & 0.5 \\
\hline
\end{tabular}

Table 1 Typical performance of the BDD cell employed by Nishiki and co-workers (Nishiki et al., 2011). 


\section{Appendix: An overview of electrode kinetics}

Consider aqueous $\mathrm{Fe}^{2+}$ and $\mathrm{Fe}^{3+}$ ions in equilibrium with an electrode at a potential $\mathrm{E} 1$; the oxidation of $\mathrm{Fe}\left(\mathrm{H}_{2} \mathrm{O}\right)_{6}{ }^{2+}$ and reduction of $\mathrm{Fe}\left(\mathrm{H}_{2} \mathrm{O}\right)_{6}{ }^{3+}$ may be represented by (Hamann et al., 2007):

$$
\mathrm{Fe}\left(\mathrm{H}_{2} \mathrm{O}\right)_{6}^{2+} \leftrightarrow \mathrm{Fe}\left(\mathrm{H}_{2} \mathrm{O}\right)_{6}{ }^{3+}+\mathrm{e}^{-}
$$

The equilibrium in equation (a1) can be represented simplistically by fig. A1.

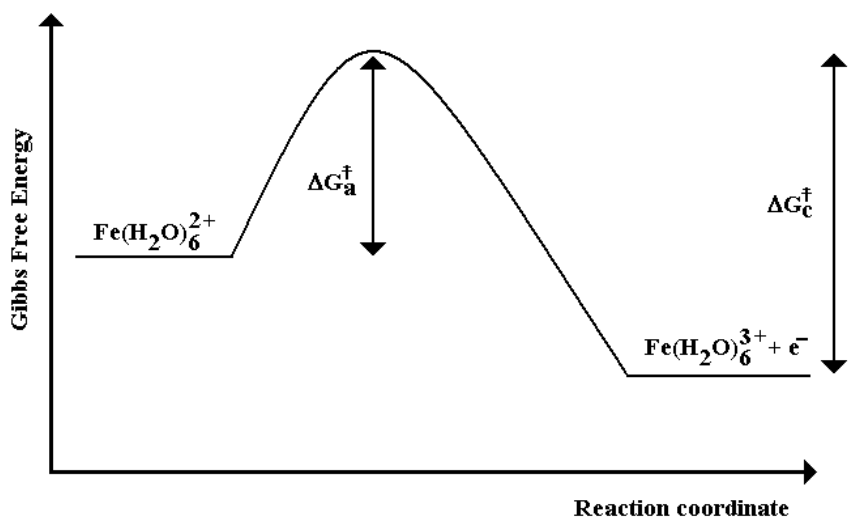

Figure A1. Schematic representation of the Gibbs Free Energy change during electron transfer between a metal electrode and the $\mathrm{Fe}\left(\mathrm{H}_{2} \mathrm{O}\right)_{6}{ }^{3+} / \mathrm{Fe}\left(\mathrm{H}_{2} \mathrm{O}\right)_{6}{ }^{2+}$ redox couple.

Electron transfer is postulated as taking place via an activated complex as shown. If the potential on the electrode is decreased from $\mathrm{E}_{1}$ to $\mathrm{E}_{2}\left(\mathrm{E}_{2}<\mathrm{E}_{1}\right.$, ie $\Delta \mathrm{E}$ is negative), only the Gibbs Free Energy of the electrons in the metal is affected, so long as neither $\mathrm{Fe}\left(\mathrm{H}_{2} \mathrm{O}\right)_{6}{ }^{3+}$ nor $\mathrm{Fe}\left(\mathrm{H}_{2} \mathrm{O}\right)_{6}{ }^{2+}$ is adsorbed, and this increases by $\Delta \mathrm{G}=-\mathrm{zF} \Delta \mathrm{E}$, where $\mathrm{z}$ is the number of electrons transferred ( $\mathrm{z}=1$ in this case) and $\mathrm{F}$ is Faraday's constant $=96485 \mathrm{C} \mathrm{mol}^{-1}$. Not all of the increase in free energy is reflected in the change in the free energy of the activated complex, since there is no change in the free energy of the $\mathrm{Fe}\left(\mathrm{H}_{2} \mathrm{O}\right)_{6}{ }^{2+}$; 


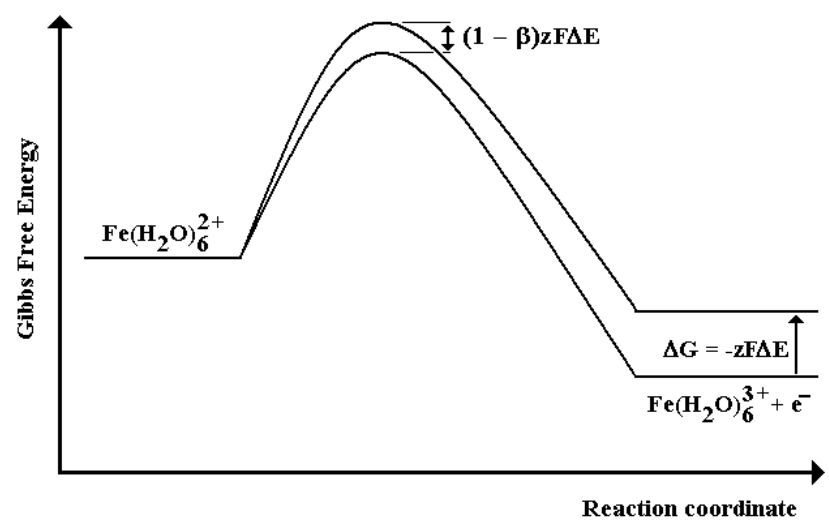

Figure A2. Schematic representation of the Gibbs Free Energy change during electron transfer between a metal electrode and the $\mathrm{Fe}\left(\mathrm{H}_{2} \mathrm{O}\right)_{6}{ }^{3+} / \mathrm{Fe}\left(\mathrm{H}_{2} \mathrm{O}\right)_{6}{ }^{2+}$ redox couple, showing the effect of decreasing the electrode potential from $E_{1}$ to $E_{2}, \Delta E=E_{1}-E_{2}$.

the fractional change in $\Delta \mathrm{G}$ is $(1-\beta)$, see fig. $A 2$, where $\beta$ is termed the asymmetry parameter, which reflects the fact that asymmetry in the position of the activated complex will be reflected in the magnitude of $\beta$ and hence in the fraction of $\Delta \mathrm{G}$ by which the free energy of the activated complex changes. If the curve is symmetrical, $\beta=0.5$, and this is very often assumed. The current density $\left(\right.$ Amps $\mathrm{cm}^{-2}$ ) of the forward (anodic) reaction is:

$$
\mathrm{J}_{\mathrm{a}}=\mathrm{k}_{\mathrm{a}}\left[\mathrm{Fe}\left(\mathrm{H}_{2} \mathrm{O}\right)_{6}{ }^{2+}\right] \exp \left(-\Delta \mathrm{G}_{\mathrm{a}}^{\ddagger} / \mathrm{RT}\right)
$$

And that of the cathodic process:

$$
\mathrm{J}_{\mathrm{c}}=\mathrm{k}_{\mathrm{c}}\left[\mathrm{Fe}\left(\mathrm{H}_{2} \mathrm{O}\right)_{6}{ }^{3+}\right] \exp \left(-\Delta \mathrm{G}_{\mathrm{c}}^{\dagger} / \mathrm{RT}\right)
$$

Straightforward development of the model represented by figs. A1 and 2 (Hamann et al., 2007; Oldham and Myland, 1994) leads to an expression for the nett current density (ie anodic - cathodic), the ButlerVolmer equation:

$$
\mathrm{j}_{\text {nett }}=\mathrm{j}_{0}[\exp \{(1-\beta) f \eta\}-\exp \{-\beta f \eta\}]
$$

where $\mathrm{j}_{0}$ is a constant, the exchange current density, $f=\mathrm{F} / \mathrm{RT}$ and $\eta$ is the overpotential: 


$$
\eta=E-E_{r}
$$

$i e$ the difference between the potential on the electrode and the potential where the nett current is zero. The overpotential reflects the energy required over and above that dictated by thermodynamics to drive an electrochemical process at the required rate (current). The exchange current density is a measure of the facile nature of the anodic and cathodic processes; the higher $\mathrm{j}_{0}$, the more rapidly equilibrium will be established at low overpotential. At an anodic overpotential $|\eta|>\mathrm{RT} / \mathrm{F}(25.7 \mathrm{mV}$ at $298 \mathrm{~K})$, the second expression, the cathodic process, can be neglected in (a4), and j becomes:

$$
\mathrm{j}_{\text {nett }}=\mathrm{j}_{0}[\exp \{(1-\beta) f \eta\}]
$$

Taking logs and re-arranging:

$$
\eta=\{2.303 /(1-\beta) f\} \cdot \log _{10} \mathrm{j}_{0}+\{2.303 /(1-\beta) f\} \cdot \log _{10} \mathrm{j}
$$

or:

$$
\eta=A+B \log _{10 j} \quad(a 8)
$$

which is the Tafel equation. The value of the asymmetry parameter is obtained from the slope of a Tafel plot, and $\mathrm{j}_{0}$ from the intercept. If $\beta=0.5$, the slope $=118 \mathrm{mV}$.

Oldham and Myland (Oldham and Myland, 1994) take this (standard) Tafel analysis further to cover more complex, multistep electrochemical reactions having chemical as well as electrochemical steps, but involving, importantly, only solution species, whilst Hamann and co-workers (Hamann et al., 2007) extend the approach still further to encompass adsorbed species. Taking the case of two sequential reactions involving solution species:

$$
\begin{aligned}
& \mathrm{A} \rightarrow \mathrm{B}+\mathrm{e}^{-} \\
& \mathrm{B} \rightarrow \mathrm{C}+\mathrm{e}^{-} \text {(a10) }
\end{aligned}
$$


Overall:

$$
\mathrm{A} \rightarrow \mathrm{C}+2 \mathrm{e}^{-}
$$

Equations (a9) - (a11) represent a general approach to multistep electrochemical reactions, in that the simultaneous transfer of two electrons is highly improbable, hence such multi-electron processes are regarded as combinations of one-electron transfers.

The kinetic treatment of (a9) and (a10) detailed below depends crucially upon the reactions achieving steady state, otherwise the derivation of simple kinetic rate laws such as Tafel equations would not be possible, as all the terms would be time-dependent. This means, in turn, that the mass transport of reactant to the electrode, and removal of products from the electrode, must be controlled through the use of, for example, rotating electrodes when acquiring data. Often, Tafel analyses are carried out on data obtained using static electrodes (see, for example, (Da Silva et al., 2001, 2003a; Da Silva et al., 2003b; Franco et al., 2006; Franco et al., 2008; Kotz and Stucki, 1987; Santana et al., 2005)), in which case, the mechanistic models derived from such studies should be addressed with care.

If (a9) is the rate-determining step, it is found that the nett current density is (Hamann et al., 2007):

$$
\mathrm{J}_{\text {nett }}=\mathrm{Fk}_{\mathrm{a}}{ }^{\prime}[\mathrm{A}] \exp \left\{\left(2-\beta_{1}\right) f \eta\right\}-\mathrm{k}_{\mathrm{c}}{ }^{\prime}[\mathrm{C}] \exp \left\{-\beta_{1} f \eta\right\}
$$

Where $\mathrm{k}_{\mathrm{a}}{ }^{\prime}$ and $\mathrm{k}_{\mathrm{c}}$ ' are the anodic and cathodic rate constants. At sufficiently high anodic overpotentials that the cathodic term in (a12) is negligible, and assuming $\beta=0.5$, gives a Tafel slope of $118 \mathrm{mV}$ for the anodic reaction.

If (a10) is the rate determining step:

$$
\mathrm{J}_{\text {nett }}=\mathrm{Fk}_{\mathrm{a}}{ }^{\prime}[\mathrm{A}] \exp \left\{\left(2-\beta_{2}\right) f \eta\right\}-\mathrm{k}_{\mathrm{c}}{ }^{\prime}[\mathrm{C}] \exp \left\{-\left(1+\beta_{2}\right) f \eta\right\}
$$

and the anodic Tafel slope will be $39 \mathrm{mV}$. As the overpotential is increased in this case, the concentration of $\mathrm{B}$ builds up such that the rate of (a10) no longer becomes rate limiting and (a9) becomes rate limiting, indicated by a switch from low Tafel slope to high. 
The model summarised above becomes significantly more complicated if adsorbed species are involved, eg. (a10) and (a11) above. In general, adsorption at electrodes is modelled with an isotherm in which the molar enthalpy of adsorption is a function of coverage, typically the Temkin isotherm which assumes that the enthalpy of adsorption at any coverage $\theta$ varies linearly with coverage:

$$
\Delta \mathrm{H}_{\theta}=\Delta \mathrm{H}_{0}+\gamma \theta \quad(\mathrm{a} 14)
$$

Where $\gamma$ is a constant and $\Delta \mathrm{H}_{0}$ molar enthalpy of adsorption when the coverage is sufficiently low for interaction between adsorbate species to be negligible compared to the interaction of these species with the surface itself. This then means that the Gibbs Free Energies of any adsorbed species will vary with coverage through the dependence of the internal energy on coverage; adsorption may then give rise to a variety of Tafel slopes.

In summary, Tafel analysis cannot be used to derive unique mechanisms from experimental data; it may be possible to demonstrate that a certain mechanism is consistent with the current/voltage data, but it can never be demonstrated that this is the only mechanism. For this reason, a plethora of in-situ spectroscopic techniques were developed from the 1980's (eg. in-situ Infra Red spectroscopy) to provide essential molecular information about intermediates and products in electrochemical reactions and hence additional evidence to eliminate mechanisms that were otherwise consistent with the current/voltage data. Finally, there is a very significant challenge in obtaining meaningful current/voltage data at high current densities involving vigorous gas evolution. 


\section{References}

Amadelli, R., L. Armelao, A.B. Velichenko, N.V. Nikolenko, D.V. Girenko, S.V. Kovalyov and F.I. Danilov, "Oxygen and ozone evolution at fluoride modified lead dioxide electrodes", Electrochim. Acta, 45(4-5): 713-720 (1999)

Amadelli, R., A. De Battisti, D.V. Girenko, S.V. Kovalyov and A.B. Velichenko, "Electrochemical oxidation of trans-3,4-dihydroxycinnamic acid at $\mathrm{PbO}_{2}$ electrodes: direct electrolysis and ozone mediated reactions compared", Electrochim. Acta, 46(2-3): 341-347 (2000)

Andrews, T. and P.G. Tait, "On the Volumetric Relations of Ozone, and the Action of the Electrical Discharge on Oxygen and Other Gases", Philosophical Transactions of the Royal Society of London, 150(*): 113 - 131 (1860)

Arihara, K., C. Terashima and A. Fujishima, "Application of freestanding perforated diamond electrodes for efficient ozone-water production", Electrochemical and Solid State Letters, 9(8): D17-D20 (2006)

Arihara, K., C. Terashima and A. Fujishima, "Electrochemical production of high-concentration ozonewater using freestanding perforated diamond electrodes", J. Electrochem. Soc., 154(4): E71E75 (2007)

Awad, M.I. and M.M. Saleh, "Electrochemical generation of ozone at $\mathrm{PbO}_{2}$-loaded platinum screens", J. Solid State Electrochem., 14(10): 1877-1883 (2010)

Awad, M.I., S. Sata, K. Kaneda, M. Ikematsu, T. Okajima and T. Ohsaka, "Ozone electrogeneration at a high current efficiency using a tantalum oxide-platinum composite electrode", Electrochem. Commun., 8(8): 1263-1269 (2006)

Babak, A.A., R. Amadelli, A. Debattisti and V.N. Fateev, "Influence of anions on oxygen/ozone evolution on $\mathrm{PbO}_{2} / \mathrm{SPE}$ and $\mathrm{PbO}_{2} / \mathrm{Ti}$ electrodes in neutral $\mathrm{pH}$ media", Electrochim. Acta, 39(1112): 1597-1602 (1994)

Bader, H. and J. Hoigne, "Determination of ozone in water by Indigo method", Water Res., 15(4): 449456 (1981)

Balej, J. and M. Thumova, "Rate of ozone formation under conditions of electrolytic production of peroxodisulfates", Collect. Czech. Chem. Commun., 39(12): 3409-3416 (1974)

Bard, A.J., R. Parsons and J. Jordan, Standard Potentials in Aqueous Solution (New York and Basel: International Union of Pure and Applied Chemistry, 1985), p. 321-339

Beaufils, Y., C. Comninellis and P. Bowen, "Preparation and characterisation of $\mathrm{Ti} / \mathrm{IrO}_{2} / \mathrm{Pb}$ electrodes for ozone production in a SPE electrochemical cell", $5^{\text {th }}$ European Symposium on Electrochemical Engineering, 145(*): 191-200 (1999)

Bockris, J.O.M. and A.K.N. Reddy, Modern Electrochemistry. 2 (New York: Plenum, 1973), p. 1101 1103

Briner, E., R. Haefeli and H. Paillard, "Sur la Production de L'ozone par L'électrolyse. Electrolyse à Basse Temperature", Helv. Chim. Acta, 20(1): 1510 - 1523 (1937)

Briner, E. and A. Yalda, "Recherches Théoriques et Expérimentales sur le Potentiel de L'électrode D'ozone", Helv. Chim. Acta, 25(6): 1188 - 1202 (1942)

Chan, K.Y. and P.A. Christensen, "Private communication", (2011)

Cheng, S.A. and K.Y. Chan, "Electrolytic generation of ozone on an antimony-doped tin dioxide coated electrode", Electrochemical and Solid State Letters, 7(3): D4-D6 (2004)

Christensen, P.A. and A. Imkum, "The Inhibition of Ozone Generation at $\mathrm{Ni} / \mathrm{Sb}-\mathrm{SnO}_{2}$ Electrodes in High Concentrations of Dissolved $\mathrm{O}_{3}$ ", Ozone-Science \& Engineering, 33(5): 389-395 (2011)

Christensen, P.A., W.F. Lin, H. Christensen, A. Imkum, J.M. Jin, G. Li and C.M. Dyson, "Room Temperature, Electrochemical Generation of Ozone with $50 \%$ Current Efficiency in $0.5 \mathrm{M}$ Sulfuric Acid at Cell Voltages < 3V", Ozone-Science \& Engineering, 31(4): 287-293 (2009) 
Christensen, P.A., K. Zakaria and T.P. Curtis, "Structure and Activity of $\mathrm{Ni}$ - and $\mathrm{Sb}-$ Doped $\mathrm{SnO}_{2}$ Ozone Anodes", Ozone-Science \& Engineering, 34(1): 49 - 56 (2012)

Cui, Y., Y. Wang, B. Wang, H. Zhou, K.-Y. Chan and X.-Y. Li, "Electrochemical Generation of Ozone in a Membrane Electrode Assembly Cell with Convective Flow", J. Electrochem. Soc., 156(4): E75-E80 (2009)

Da Silva, L.M., L.A. De Faria and J.F.C. Boodts, "Green processes for environmental application. Electrochemical ozone production", Pure Appl. Chem., 73(12): 1871-1884 (2001)

Da Silva, L.M., L.A. De Faria and J.F.C. Boodts, "Eletrochemical ozone production: influence of the supporting electrolyte on kinetics and current efficiency", Electrochimica Acta, 48(6): 699-709 (2003a)

Da Silva, L.M., D.V. Franco, J.C. Forti, W.F. Jardim and J.F.C. Boodts, "Characterisation of a laboratory electrochemical ozonation system and its application in advanced oxidation processes", J. Appl. Electrochem., 36(5): 523-530 (2006)

Da Silva, L.M., D.V. Franco, L.G. Sousa and I.C. Goncalves, "Characterization of an electrochemical reactor for the ozone production in electrolyte-free water", J. Appl. Electrochem., 40(4): 855864 (2010)

Da Silva, L.M., M.H.P. Santana and J.F.C. Boodts, "Electrochemistry and green chemical processes: Electrochemical ozone production", Quim. Nova, 26(6): 880-888 (2003b)

De Smedt, F., S. De Gendt, M.M. Heyns and C. Vinckier, "The application of ozone in semiconductor cleaning processes - The solubility issue", J. Electrochem. Soc., 148(9): G487-G493 (2001)

Eliasson, B. and U. Kogelschatz, "Electron-impact dissociation in oxygen", Journal of Physics BAtomic Molecular and Optical Physics, 19(8): 1241-1247 (1986)

Elshal, W., H. Khordagui, O. Elsebaie, F. Elsharkawi and G.H. Sedahmed, "Electrochemical generation of ozone for water - treatment using a cell operating under natural-convection", Desalination, 99(1): 149-157 (1994)

Feng, J.R., D.C. Johnson, S.N. Lowery and J.J. Carey, "Electrocatalysis of anodic oxygen - transfer reactions - evolution of ozone", J. Electrochem. Soc., 141(10): 2708-2711 (1994)

Fischer, F. and K. Bendixsohn, "Über die Ozonbildung an ruhenden Strichanoden", Zeitschrift für anorganische Chemie, 61(1): 153 - 180 (1909)

Fischer, F. and K. Massenez, "Über die Darstellung von Ozon durch Elektrolyse. Zeitschrift für anorganische Chemie", Zeitschrift für anorganische Chemie, 52(1): 202 - 218 (1907)

Foller, P.C. and G.H. Kelsall, "Ozone generation via the electrolysis of fluoboric acid using glassy carbon anodes and air depolarized cathodes", J. Appl. Electrochem., 23(10): 996-1010 (1993)

Foller, P.C. and C.W. Tobias, "The anodic evolution of ozone", J. Electrochem. Soc., 129(3): 506-515 (1982)

Franco, D.V., L.M. Da Silva, W.F. Jardim and J.F.C. Boodts, "Influence of the electrolyte composition on the kinetics of the oxygen evolution reaction and ozone production processes", Journal of the Brazilian Chemical Society, 17(4): 746-757 (2006)

Franco, D.V., W.F. Jardim, J.F.C. Boodts and L.M. Da Silva, "Electrochemical ozone production as an environmentally friendly technology for water treatment", Clean-Soil Air Water, 36(1): 34-44 (2008)

Gordon, G., G.E. Pacey, W.J. Cooper and R.G. Rice, "Current state - of - the - art measurements of ozone in the gas-phase and in solution", Ozone-Science \& Engineering, 10(4): 353-365 (1988)

Graves, J.E., D. Pletcher, R.L. Clarke and F.C. Walsh, "The electrochemistry of magneli phase titanium - oxide ceramic electrodes. 2. ozone generation at ebonex and ebonex lead dioxide anodes", $J$. Appl. Electrochem., 22(3): 200-203 (1992)

Hamann, C.H., A. Hamnett and W. Vielstich, Electrochemistry (Weinheim: Wiley-VCH, 2007), p. 162 $-179$ 
Han, S.D., J.D. Kim, K.S. Myung, R.K. Rana and K.C. Singh, "Electro-chemical production of ozone using water electrolysis cell of solid polymer electrolyte (SPE)", Indian J. Chem. Technol., 13(2): 156-161 (2006)

Hickling, A. and S. Hill, "Oxygen Overvoltage Part III.-A Note on the Standard Potentials of the Hydroxyl Radical and Atomic Oxygen", Transactions of the Faraday Society, 46(0): 557 - 559 (1950)

Hoigne, J. and H. Bader, "Role of hydroxyl radical reactions in ozonation processes in aqueous solution", Water Res., 10(5): 377-386 (1976)

Holt, R.B., C.K. McLane and O. Oldenberg, "Ultraviolet Absorption Spectrum of Hydrogen Peroxide", The Journal of Chemical Physics, 16(3): 225 - 229 (1948)

Kaneda, K., M. Ikematsu, K. Kitsuka, M. Iseki, H. Matsuura, T. Higuchi, T. Hattori, T. Tsukamoto and M. Yasuda, "Si/TiOx/Pt/TaOx electrodes fabricated by sputtering for electrochemical ozone generation", Japanese Journal of Applied Physics Part 1-Regular Papers Brief Communications \& Review Papers, 45(8A): 6417-6419 (2006)

Kaneda, K., M. Ikematsu, Y. Koizumi, H. Minoshima, T. Rakuma, D. Takaoka and M. Yasuda, "Ozone generation by a $\mathrm{TaOx}$ and $\mathrm{Pt}$ composite insulator-coated Ti electrode", Electrochemical and Solid State Letters, 8(6): J13-J16 (2005)

Kapalka, A., G. Foti and C. Comninellis, "The importance of electrode material in environmental electrochemistry Formation and reactivity of free hydroxyl radicals on boron-doped diamond electrodes", Electrochimica Acta, 54(7): 2018-2023 (2009)

Katoh, M., Y. Nishiki and S. Nakamatsu, "A Study on Electrochemical Ozone Generator Using Oxygen Gas Diffusion Cathode", Meeting of the Journal Electrochemcial Society, (1992)

Katoh, M., Y. Nishiki and S. Nakamatsu, "Polymer electrolyte - type electrochemical ozone generator with an oxygen cathode", J. Appl. Electrochem., 24(6): 489-494 (1994)

Katsuki, N., E. Takahashi, M. Toyoda, T. Kurosu, M. Iida, S. Wakita, Y. Nishiki and T. Shimamune, "Water electrolysis using diamond thin-film electrodes", J. Electrochem. Soc., 145(7): 23582362 (1998)

Kilpatrick, M.L., C.C. Herrick and M. Kilpatrick, "The Decomposition of Ozone in Aqueous Solution", J. Am. Chem. Soc., 78(9): 1784 - 1789 (1956)

Kim, J. and G.V. Korshin, "Examination of in situ generation of hydroxyl radicals and ozone in a flowthrough electrochemical reactor", Ozone-Science \& Engineering, 30(2): 113-119 (2008)

Kitsuka, K., K. Kaneda, M. Ikematsu, M. Iseki, K. Mushiake and T. Ohsaka, "Ex situ and in situ characterization studies of spin-coated $\mathrm{TiO}_{2}$ film electrodes for the electrochemical ozone production process", Electrochim. Acta, 55(1): 31-36 (2009)

Kitsuka, K., K. Kaneda, M. Ikematsu, M. Iseki, K. Mushiake and T. Ohsaka, "n-Type $\mathrm{TiO}_{2}$ Thin Films for Electrochemical Ozone Production", J. Electrochem. Soc., 157(2): F30-F34 (2010)

Kotz, E.R. and S. Stucki, "Ozone and oxygen evolution on $\mathrm{PbO}_{2}$ electrodes acid - solution", J. Electroanal. Chem., 228(1-2): 407-415 (1987)

Kraft, A., M. Stadelmann, M. Wunsche and M. Blaschke, "Electrochemical ozone production anodes and a solid polymer using diamond electrolyte", Electrochem. Commun., 8(5): 883-886 (2006)

Larminie, J. and A. Dicks, Fuel cell systems explained (Chichester: Wiley, 2003), p. 69 - 72

Lash, E.I., R.D. Hornbeck, G.L. Putnam and E.D. Boleter, "Production of Ozone with Refrigerated Anodes", Journal of Electrochemical Society, 98(4): 134-137 (1951)

Levanov, A.V., I.V. Kuskov, E.E. Antipenko and V.V. Lunin, "The solubility of ozone in aqueous solutions of sulfuric, phosphoric, and perchloric acids", Russian Journal of Physical Chemistry A, 82(7): 1126-1131 (2008)

Li, H., Y. Tang, Z. Wang, Z. Shi, S. Wu, D. Song, J. Zhang, K. Fatih, J. Zhang, H. Wang, Z. Liu, R. Abouatallah and A. Mazza, "A review of water flooding issues in the proton exchange membrane fuel cell", J. Power Sources, 178(1): 103-117 (2008) 
Marselli, B., J. Garcia-Gomez, P.A. Michaud, M.A. Rodrigo and C. Comninellis, "Electrogeneration of hydroxyl radicals on boron-doped diamond electrodes", J. Electrochem. Soc., 150(3): D79-D83 (2003)

Martinez-Huitle, C.A. and E. Brillas, "Decontamination of wastewaters containing synthetic organic dyes by electrochemical methods: A general review", Applied Catalysis B-Environmental, 87(34): 105-145 (2009)

Mazza, B., P. Pedeferri and G. Re, "Hydrodynamic instabilities in electrolytic gas evolution", Electrochim. Acta, 23(2): 87-93 (1978)

Meyer, C.P., C.M. Elsworth and I.E. Galbally, "Water - vapor interference in the measurement of ozone in ambient air by ultraviolet - absorption", Rev. Sci. Instrum., 62(1): 223-228 (1991)

Michaud, P.A., E. Mahe, W. Haenni, A. Perret and C. Comninellis, "Preparation of peroxodisulfuric acid using boron-doped diamond thin film electrodes", Electrochemical and Solid State Letters, 3(2): 77-79 (2000)

Michaud, P.A., M. Panizza, L. Ouattara, T. Diaco, G. Foti and C. Comninellis, "Electrochemical oxidation of water on synthetic boron-doped diamond thin film anodes", J. Appl. Electrochem., 33(2): 151-154 (2003)

Nemes, A., I. Fabian and G. Gordon, "Experimental aspects of mechanistic studies on aqueous ozone decomposition in alkaline solution", Ozone-Science \& Engineering, 22(3): 287-304 (2000)

Nishiki, Y., N. Kitaori and K. Nakamuro, "Performances of Small-Sized Generator of Ozone-Dissolved Water Using Boron-Doped Diamond Electrodes", Ozone Sci. Eng., 33(2): 114-120 (2011)

Okada, F. and K. Naya, "Highly Efficient and Long-Lifetime Ozone Water Production System Realized Using a Felt Separator", J. Electrochem. Soc., 156(8): E125-E131 (2009)

Okada, T., S. Moller-Holst, O. Gorseth and S. Kjelstrup, "Transport and equilibrium properties of Nafion membranes with $\mathrm{H}^{+}$and $\mathrm{Na}^{+}$ions", J. Electroanal. Chem., 442(1-2): 137-145 (1998)

Oldham, K.B. and J.C. Myland, Fundamentals of Electrochemical Science (San Diego: Academic Press Incorporated 1994), p. 167 - 176

Onda, K., T. Ohba, H. Kusunoki, S. Takezawa, D. Sunakawa and T. Araki, "Improving characteristics of ozone water production with multilayer electrodes and operating conditions in a polymer electrolyte water electrolysis cell", J. Electrochem. Soc., 152(10): D177-D183 (2005)

Panizza, M. and G. Cerisola, "Application of diamond electrodes to electrochemical processes", Electrochim. Acta, 51(2): 191-199 (2005)

Phibbs, M.K. and P.A. Giguere, "Hydrogen peroxide and its analogues. III. Absorption spectrum of hydrogen and deuterium peroxides in the near ultra-violet", Can. J. Chem., 29(6): 490-493 (1951)

Putnam, G.L., R.W. Moulton, W.W. Fillmore and L.H. Clark, "Electrolytic Ozone", J. Electroanal. Chem., 93(5): 211 - 221 (1948)

Putnam, G.L., Moulton, R. W., Fillmore, W. W., Clark, L. H., "Electrolytic Ozone", Journal of Electroanalytical Chemistry, 93(5): 211 - 221 (1948)

Rakness, K., G. Gordon, B. Langlais, W. Masschelein, N. Matsumoto, Y. Richard, C.M. Robson and I. Somiya, "Guideline for measurement of ozone concentration in the process gas from an ozone generator", Ozone-Science \& Engineering, 18(3): 209-229 (1996)

Rau, S., "Private comunications", AirTree Europe GmbH, (2009)

Rubin, M.B., "The History of Ozone. The Schönbein. Period, 1839-1868", Bull. Hist. Chem., 26(1): 40 - $56(2001)$

Santana, M.H.P., L.A. De Faria and J.F.C. Boodts, "Investigation of the properties of Ti/[ $\left[\mathrm{IrO}_{2}-\mathrm{Nb}_{2} \mathrm{O}_{5}\right]$ electrodes for simultaneous oxygen evolution and electrochemical ozone production, EOP", Electrochim. Acta, 49(12): 1925-1935 (2004)

Santana, M.H.P., L.A. De Faria and J.F.C. Boodts, "Effect of preparation procedure of $\mathrm{IrO}_{2}-\mathrm{Nb}_{2} \mathrm{O}_{5}$ anodes on surface and electrocatalytic properties", J. Appl. Electrochem., 35(9): 915-924 (2005) 
Sawyer, C.N., P.L. McCarty and G.F. Parkin, Chemistry for environmental engineering and science (Singapore: McGraw-Hill Science Engineering, 2002), p. 563 - 569

Schönbein, C.F., "Lecture of 13 March 1839", Bericht über die Verhandlungen der Naturforschenden Gesellschaft in Basel, 4(58): (1838-1840)

Schönbein, C.F., "On the Odour Accompanying Electricity and on the Probability of its Dependence on the Presence of a New Substance", Philos. Mag. (III), 17(*): 293 - 294 (1840a)

Schönbein, C.F., "Recherches sur la nature de l'odeur, qui se manifeste dans certaines actions chimiques", Seances Acad. Sci. Ser. C, 10(*): 706 - 710 (1840b)

Seader, J.D. and C.W. Tobias, "Ozone by Electrolysis of Sulfuric Acid", Ind. Eng. Chem., 44(9): 2207 - 2211 (1952)

Sehested, K., H. Corfitzen, J. Holcman and E.J. Hart, "On the mechanism of the decomposition of acidic $\mathrm{O}_{3}$ solutions, thermally or $\mathrm{H}_{2} \mathrm{O}_{2}$-initiated", J. Phys. Chem. A, 102(16): 2667-2672 (1998)

Seidel, A., Kirk-Othmer Encyclopedia of Chemical Technology (New Jersey: John Wiley \& Sons, Inc, 2006), p. $768-822$

Stucki, S., H. Baumann, H.J. Christen and R. Kotz, "Performance of a pressurized electrochemical ozone generator", J. Appl. Electrochem., 17(4): 773-778 (1987)

Stucki, S., G. Theis, R. Kotz, H. Devantay and H.J. Christen, "Insitu production of ozone in water using a membrel electrolyzer", J. Electrochem. Soc., 132(2): 367-371 (1985)

Tatapudi, P. and J.M. Fenton, "Synthesis of ozone in proton - exchange membrane electrochemical reactor", J. Electrochem. Soc., 140(12): 3527-3530 (1993)

Tatapudi, P. and J.M. Fenton, "Simultaneous synthesis of ozone and hydrogen - peroxide in a proton exchange - membrane electrochemical reactor", J. Electrochem. Soc., 141(5): 1174-1178 (1994)

Trogadas, P., E. Pinot and T.F. Fuller, "Composite, Solvent-Casted Nafion Membranes for Vanadium Redox Flow Batteries", Electrochemical and Solid State Letters, 15(1): A5-A8 (2012)

Valdes, T.I. and F. Moussy, "A ferric chloride pre-treatment to prevent calcification of Nafion membrane used for implantable biosensors", Biosensors \& Bioelectronics, 14(6): 579-585 (1999)

Velichenko, A.B., R. Amadelli, A. Benedetti, D.V. Girendko, S.V. Kovalyov and F.I. Danilov, "Electrosynthesis and physicochemical properties of $\mathrm{PbO}_{2}$ films", J. Electrochem. Soc., 149(9): C445-C449 (2002)

Wabner, D. and C. Grambow, "Reactive intermediates during oxidation of water at lead dioxide and platinum - electrodes", J. Electroanal. Chem., 195(1): 95-108 (1985)

Wang, Y.-H., S. Cheng and K.-Y. Chan, "Synthesis of ozone from air via a polymer-electrolytemembrane cell with a doped tin oxide anode", Green Chemistry, 8(6): 568-572 (2006)

Wang, Y.H., S.A. Cheng, K.Y. Chan and X.Y. Li, "Electrolytic generation of ozone on antimony- and nickel-doped tin oxide electrode", J. Electrochem. Soc., 152(11): D197-D200 (2005)

Wen, T.C. and C.C. Chang, "The structural - changes of $\mathrm{PbO}_{2}$ anodes during ozone evolution", J. Electrochem. Soc., 140(10): 2764-2770 (1993)

(*): the issue is not available 


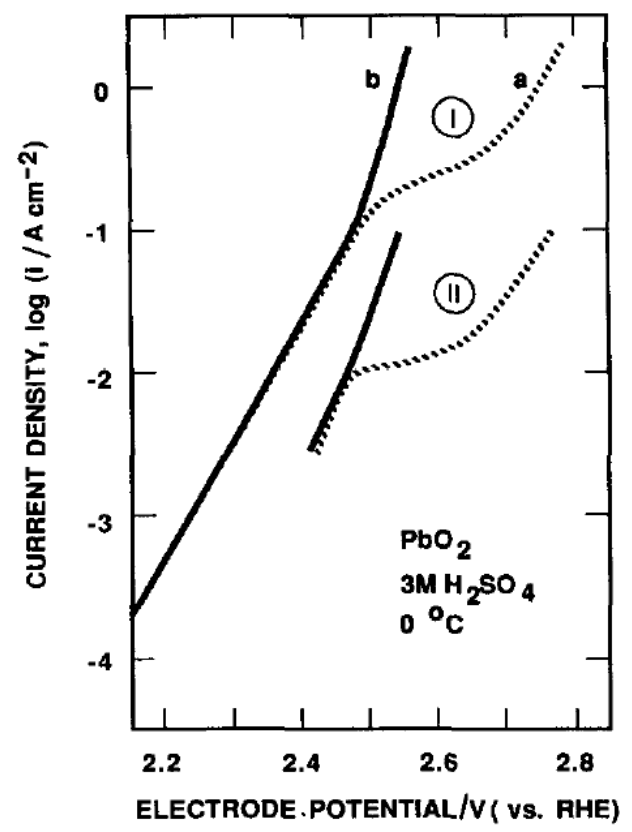

Figure 1. Current-potential curves for $\mathrm{PbO}_{2}$ in $3 \mathrm{M} \mathrm{H}_{2} \mathrm{SO}_{4}$ at $\mathrm{O}^{\circ} \mathrm{C}$. Curves (I) are the total current \& curves (Katsuki et al.) the partial currents for $\mathrm{O}_{3}$ evolution calculated from the measured values of the $\mathrm{O}_{3}$ concentration in the anode product gas. IR correction carried out via (-) current interruption or (...) positive feedback. Reproduced with permission from (Kotz and Stucki, 1987).

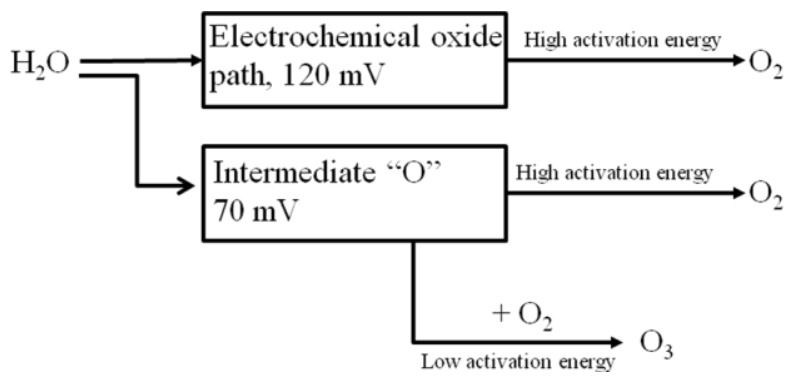

Figure 2. The mechanism for the electrochemical generation of ozone proposed by Kötz and Stucki. Redrawn from (Kotz and Stucki, 1987). 


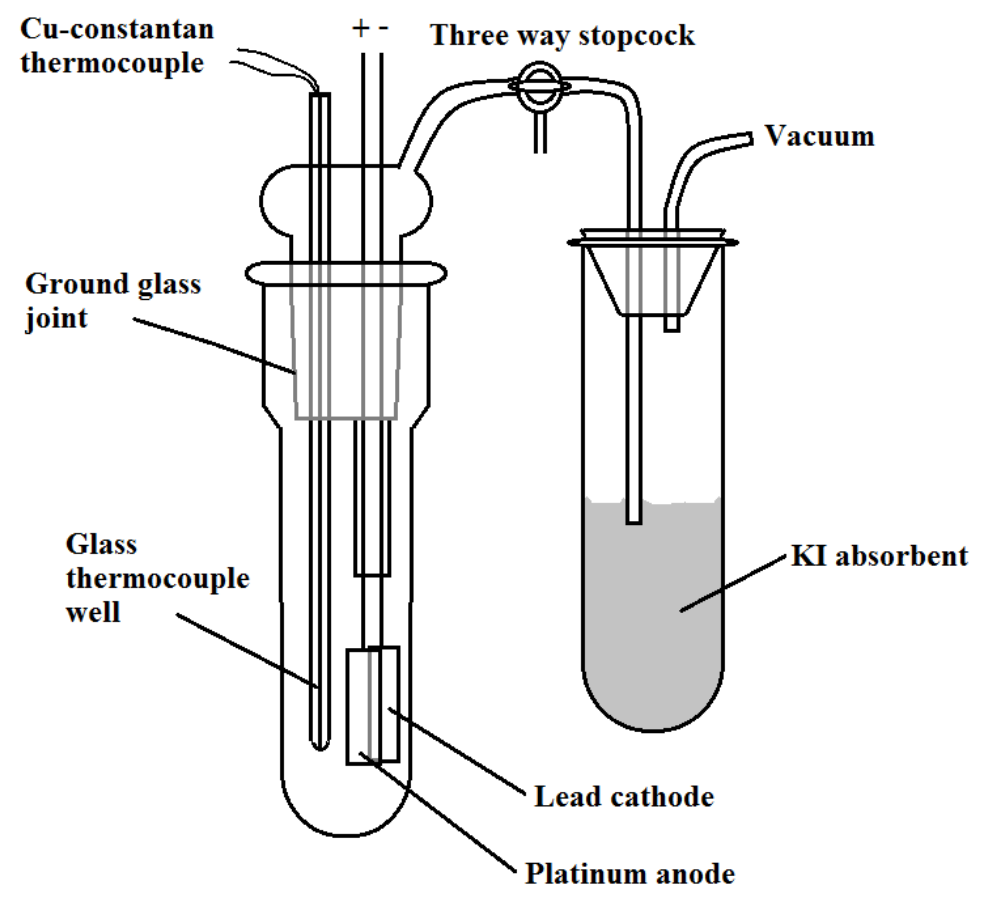

Figure 3. Single compartment electrochemical cell; anode and cathode gases mix. Redrawn from (Putnam et al., 1948).

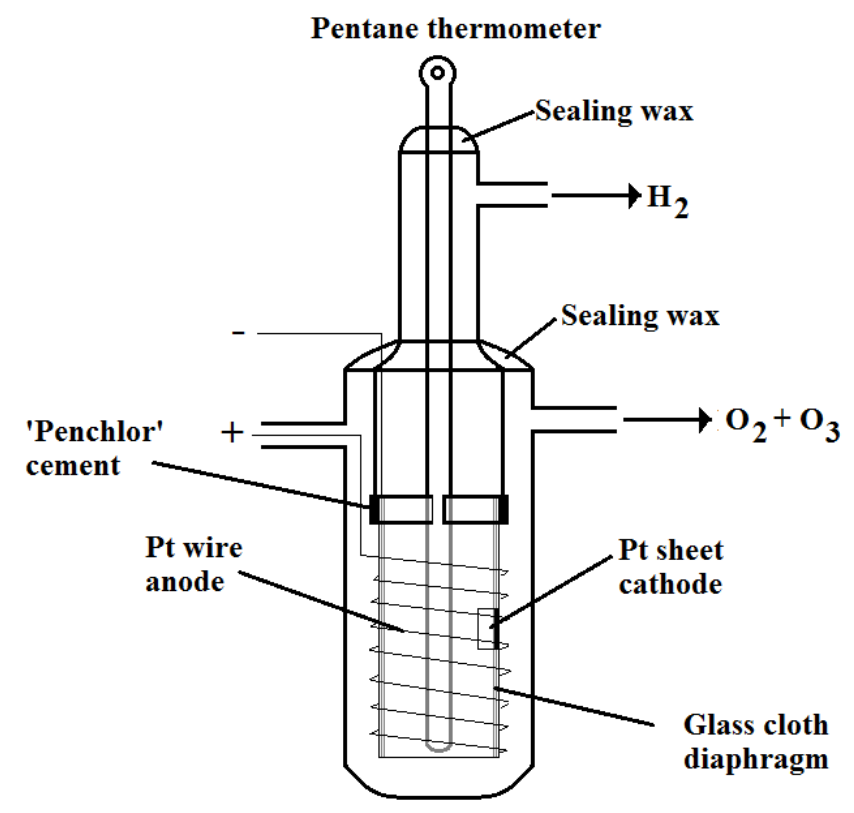

(a) 


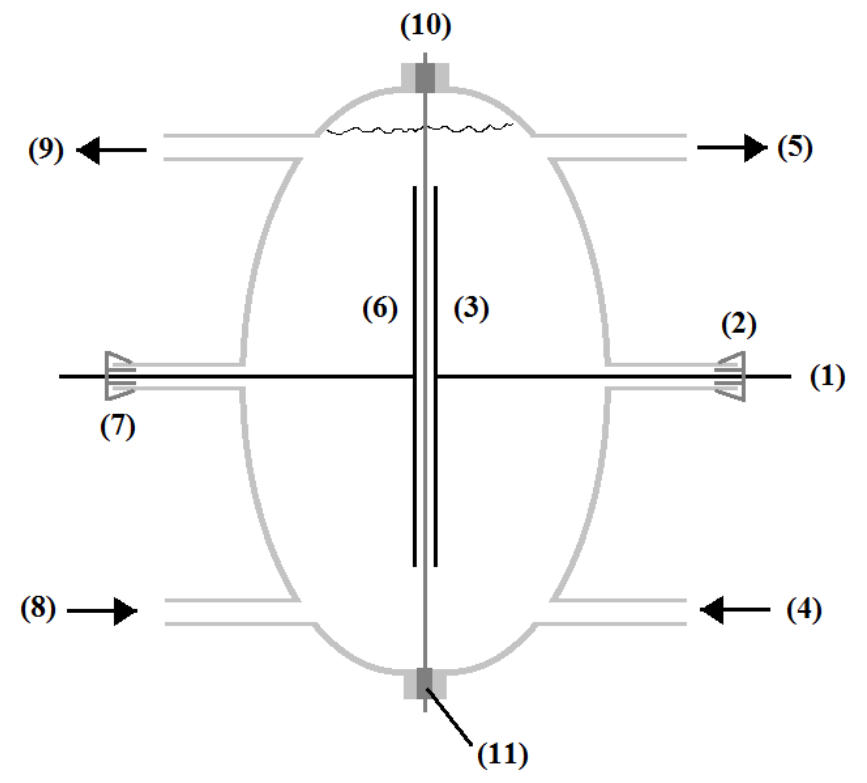

(b)

Figure 4. Cells where the anode and cathode gases are kept separated. (a) The Diaphragm laboratory cell employed by Putnam et al.; the anolyte and catholyte are separated by a glass cloth diaphragm. Redrawn from (Putnam et al., 1948). (b) The separated cell employed by Christensen and co-workers (Christensen et al., 2009); the anolyte and catholyte are separated by a Nafion membrane and the two hemispherical glass sections of the cell are clamped either side of the membrane with silicone seals. (1) Ti wire, (2) rubber seal, (3) Pt/Ti mesh cathode, (4) catholyte inlet, (5) catholyte outlet, (6) Ni/Sb$\mathrm{SnO}_{2}$ coated Ti mesh anode, (7) rubber seal, (8) anolyte inlet, (9) anolyte outlet, (10) Nafion membrane and (11) silicone rubber " $O$ " ring seals. 


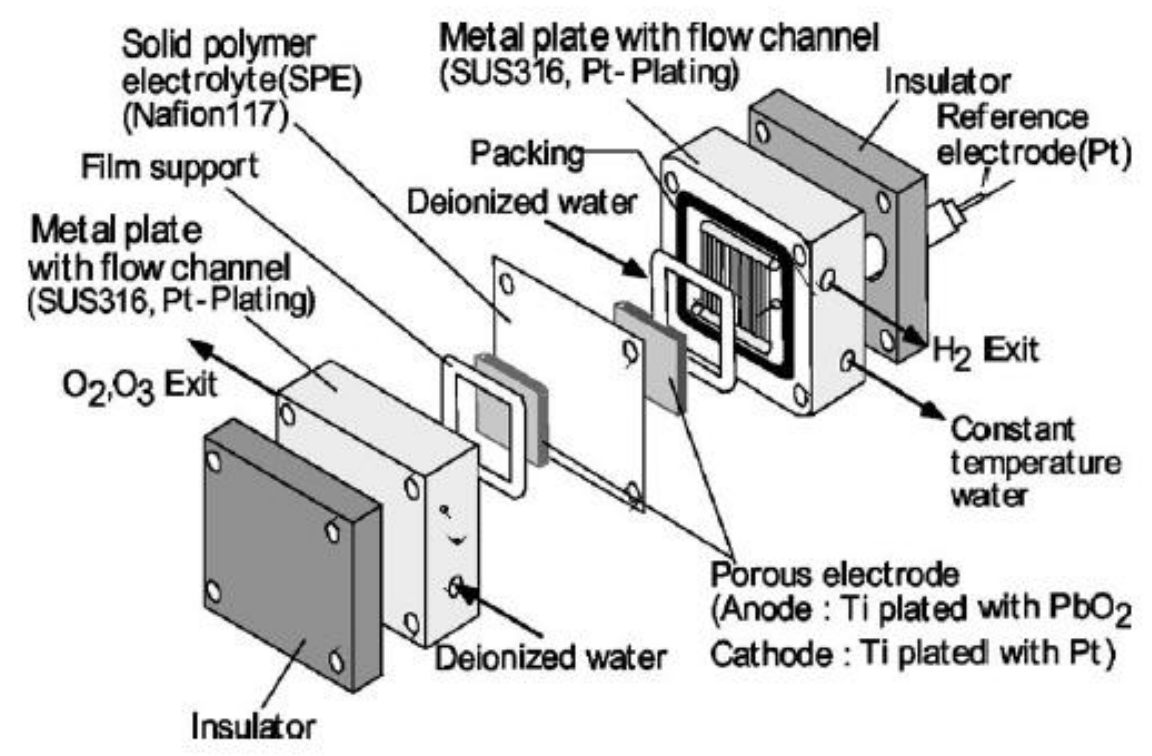

Figure 5 Schematic of the solid polymer electrolyte membrane cell employed by Onda and coworkers (Onda et al., 2005). Reproduced with permission.

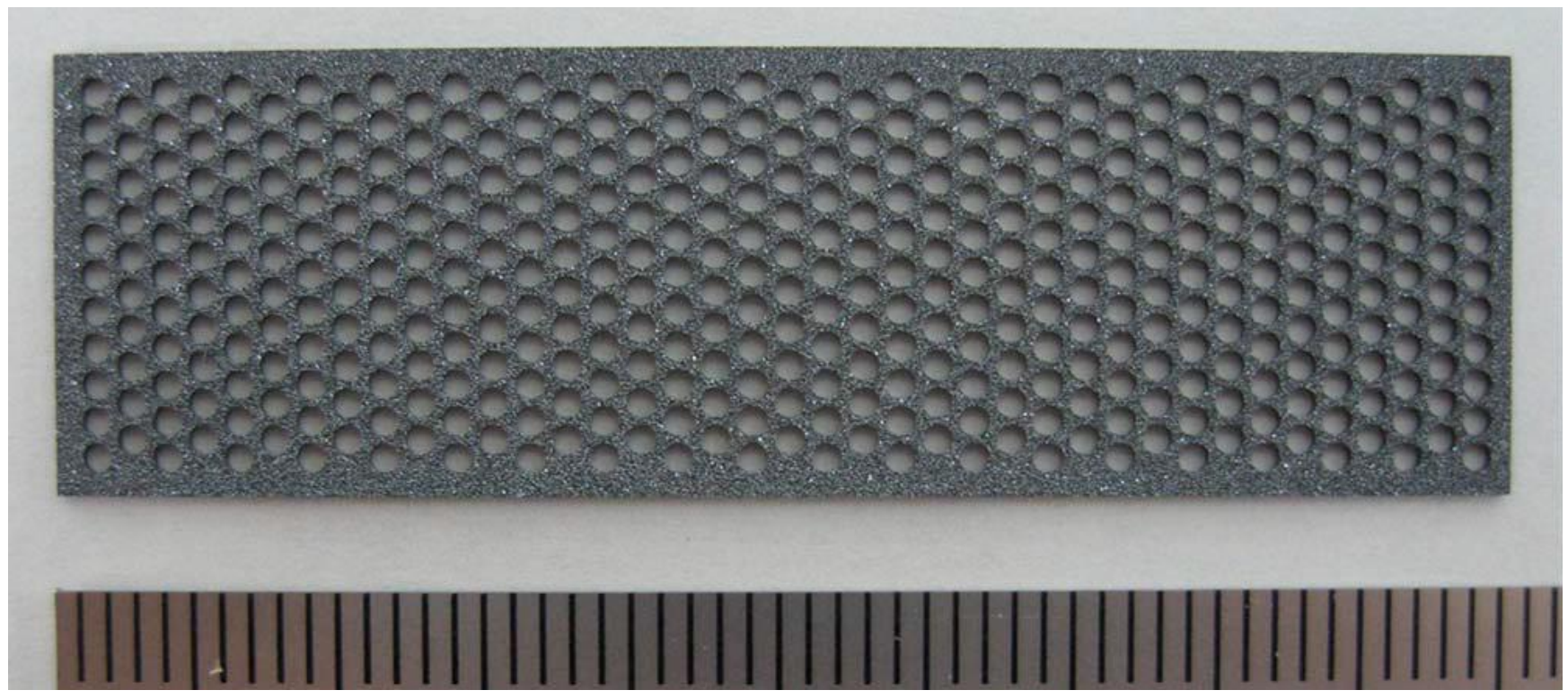

Figure 6. Photograph of an example of the free-standing, perforated Boron Doped Diamond electrodes employed by Arihara and co-workers (Arihara et al., 2006; Arihara et al., 2007). Reproduced with permission. 


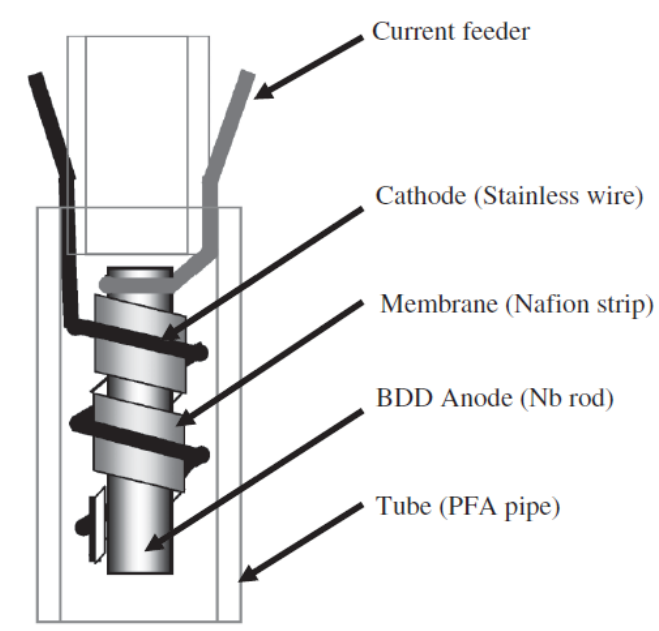

Figure 7. The cell employed by Nishiki et al (Nishiki et al., 2011). Reproduced with permission.

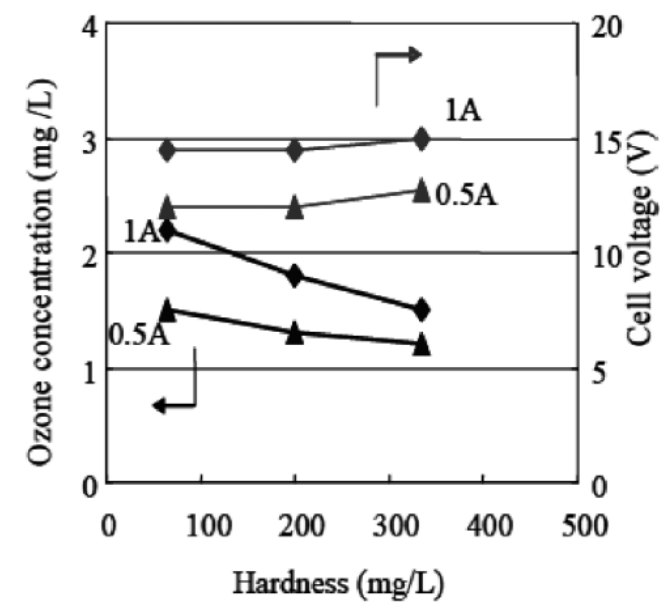

Figure 8. The dependence of ozone concentration and cell voltage on hardness observed by Nishiki et al (Nishiki et al., 2011). Reproduced with permission. 


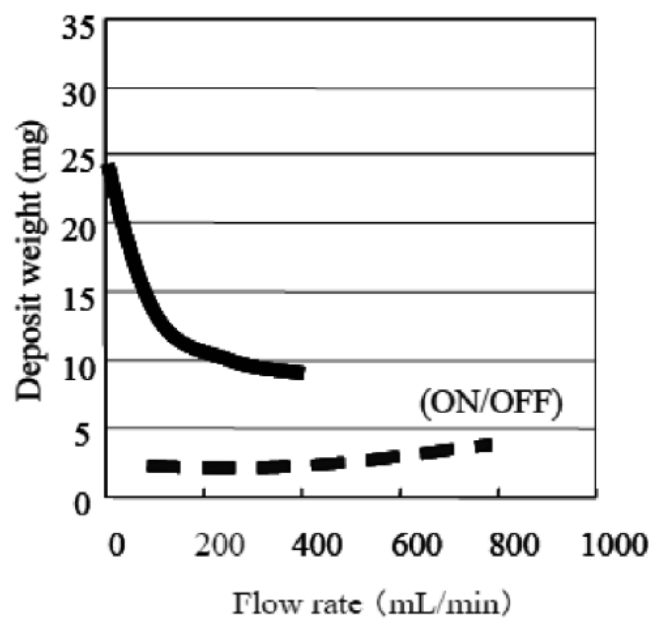

Figure 9. The increase in mass of the Nafion membrane employed by Nishiki and co-workers (Nishiki et al., 2011) following 2 hours electrolysis at 1 A under constant current operation, and with current on for 8 minutes and off for 2 minutes. Reproduced with permission.

Cover
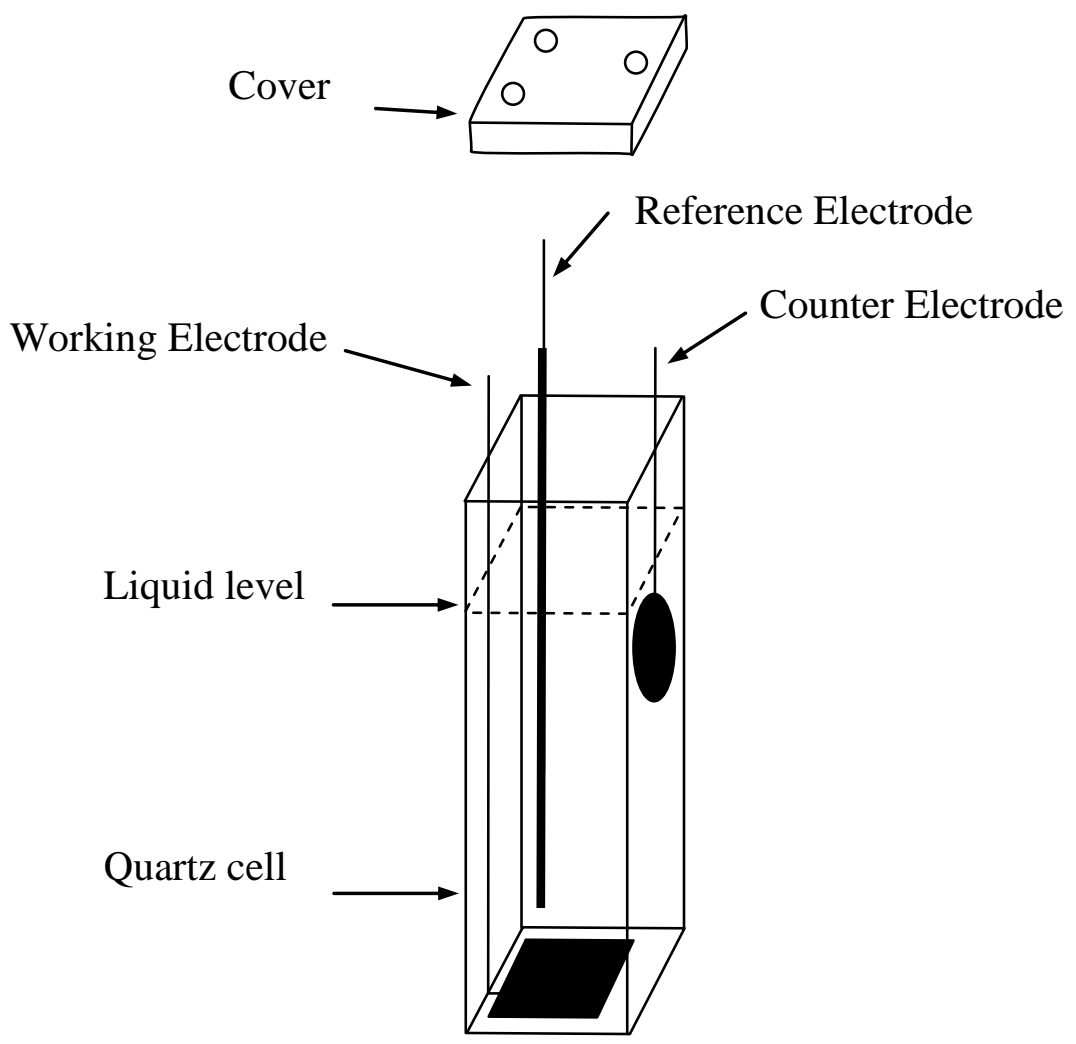

Figure 10. Schematic of the electrolysis UV cell employed by Wang et al. showing the arrangement of the working electrode, reference electrode, and the counter electrode. From (Wang et al., 2005) with permission. 

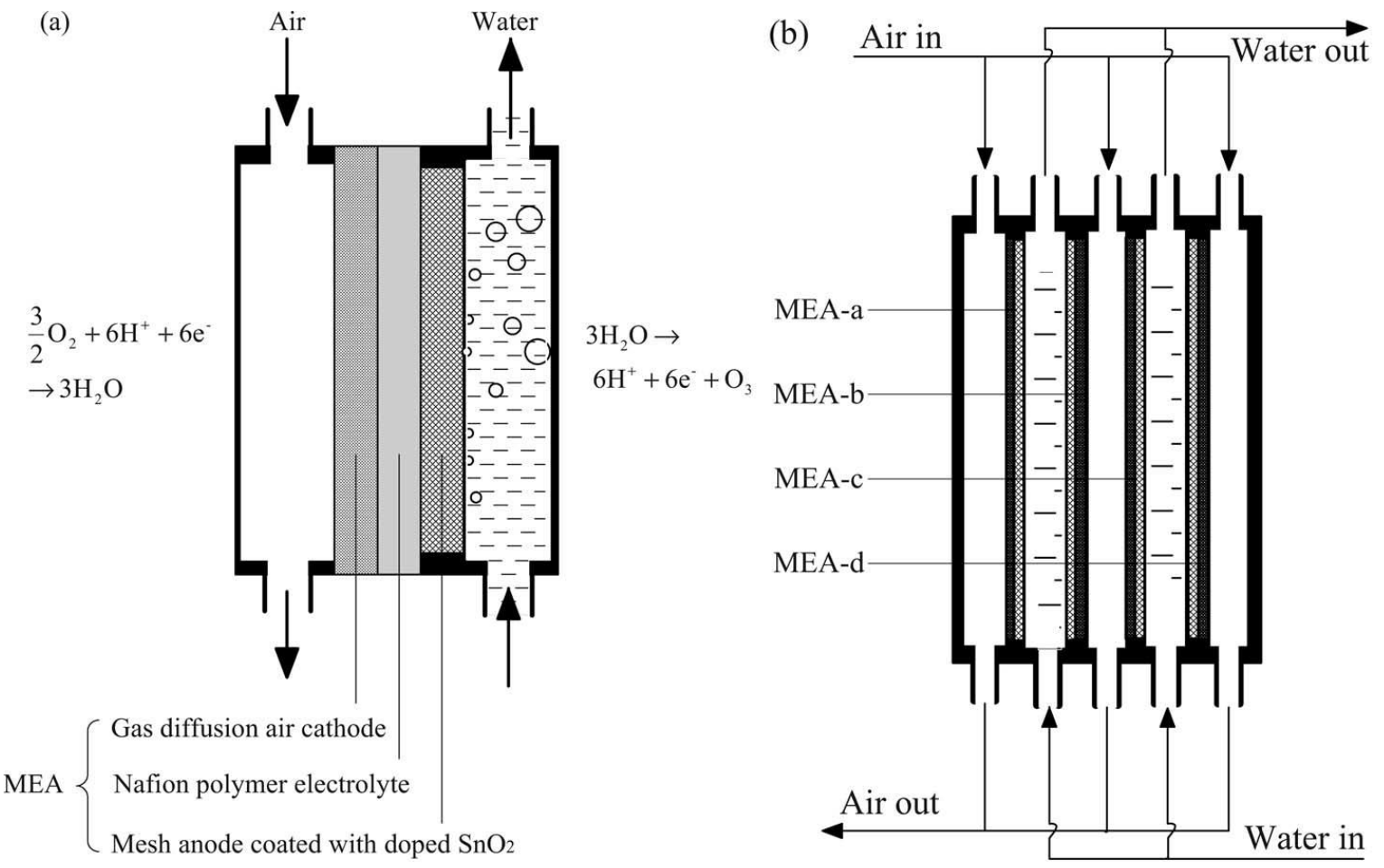

(c)

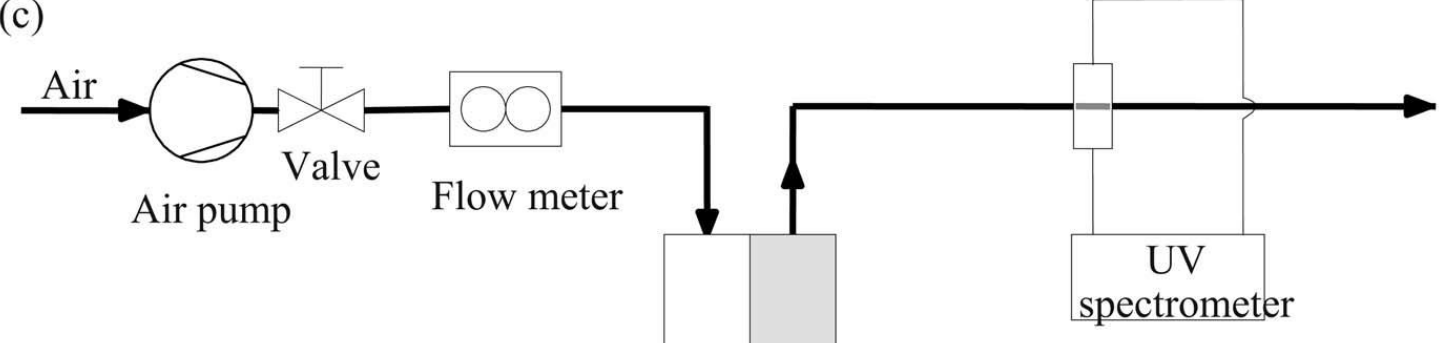

Electrochemical
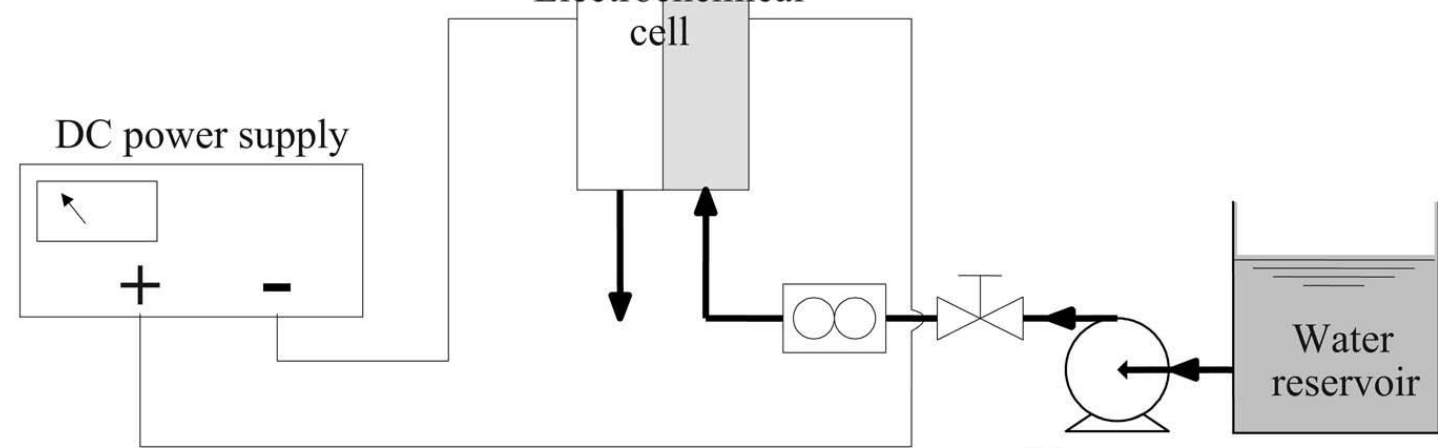

Water pump

Figure 11. (a) The single cell, (b) 4-cell stack and (c) balance of plant employed by Cui et al (Cui et al., 2009). Reprinted with permission. 


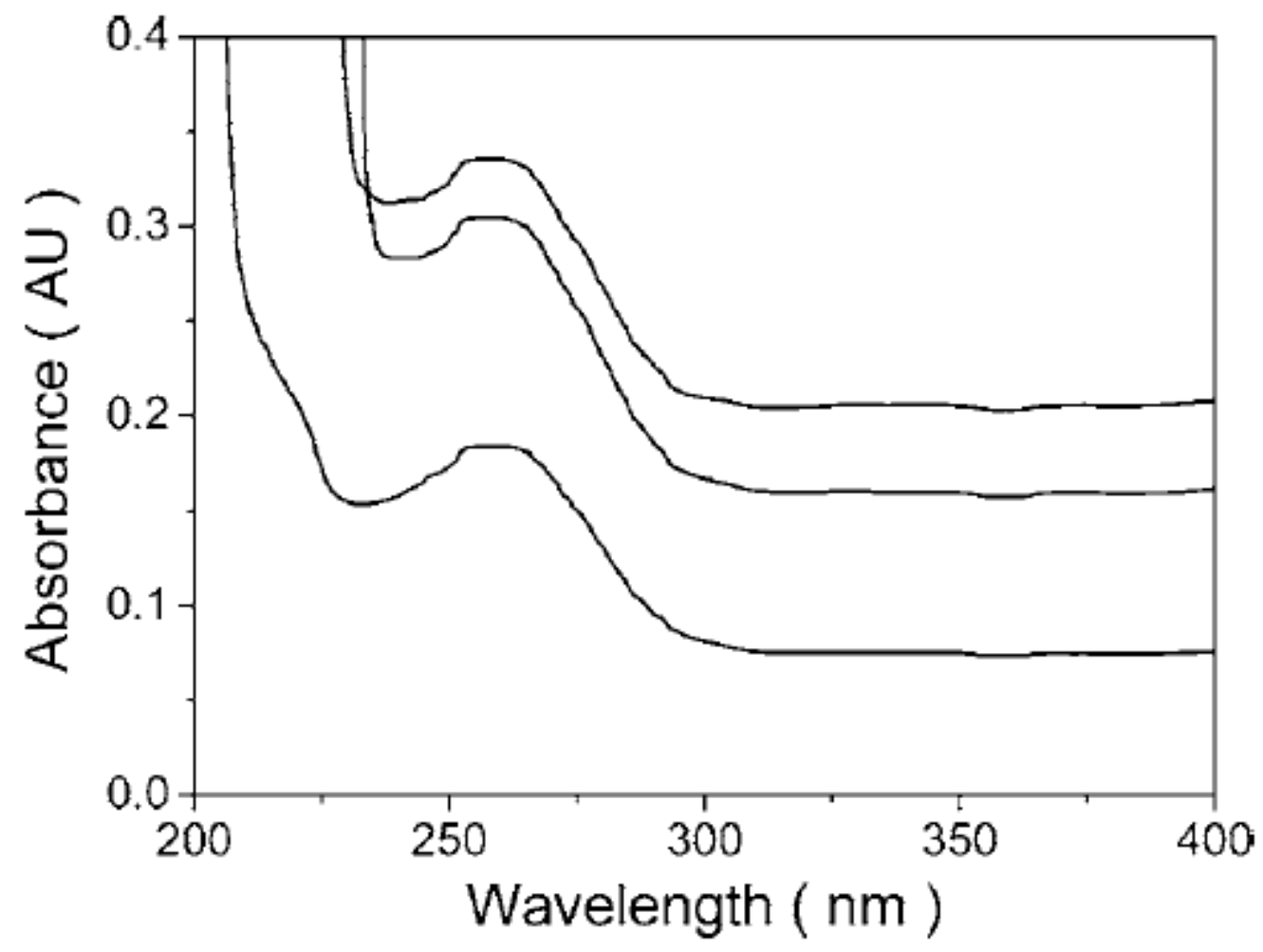

Figure 12. Typical spectra obtained during the operation of the flow cell. Reprinted from Cui et al. (Cui et al., 2009) with permission. 